\title{
The Antidiabetic Effects and Modes of Action of the Balanites aegyptiaca Fruit and Seed Aqueous Extracts in NA/STZ-Induced Diabetic Rats
}

\author{
Asmaa S. Zaky ${ }^{1}$, Mohamed Kandeil ${ }^{2}{ }^{(}$, Mohamed Abdel-Gabbar ${ }^{1}{ }^{10}$, Eman M. Fahmy $^{3}$, \\ Mazen M. Almehmadi ${ }^{4}\left(\mathbb{D}\right.$, Tarek M. Ali ${ }^{5}$ (D) and Osama M. Ahmed ${ }^{6, *(D)}$ \\ 1 Biochemistry Department, Faculty of Science, Beni-Suef University, Beni-Suef P.O. Box 62521, Egypt; \\ asmaa_zaky221@yahoo.com (A.S.Z.); hhmgabar@yahoo.com (M.A.-G.) \\ 2 Biochemistry Department, Faculty of Veterinary Medicine, Beni-Suef University, \\ Beni-Suef P.O. Box 62521, Egypt; mohamed.kandeal@vet.bsu.edu.eg \\ 3 Department of Internal Medicine, Faculty of Medicine, Helwan University, Helwan 11795, Egypt; \\ dremf@hotmail.com \\ 4 Department of Clinical Laboratory Sciences, College of Applied Medical Sciences, Taif University, \\ P.O. Box 11099, Taif 21944, Saudi Arabia; dr.mazen.ma@gmail.com \\ 5 Department of Physiology, College of Medicine, Taif University, P.O. Box 11099, Taif 21944, Saudi Arabia; \\ tarek70ali@gmail.com \\ 6 Physiology Division, Department of Zoology, Faculty of Science, Beni-Suef University, \\ Beni-Suef P.O. Box 62521, Egypt \\ * Correspondence: osamamoha@yahoo.com or osama.ahmed@science.bsu.edu.eg
}

Citation: Zaky, A.S.; Kandeil, M.; Abdel-Gabbar, M.; Fahmy, E.M.; Almehmadi, M.M.; Ali, T.M.; Ahmed, O.M. The Antidiabetic Effects and Modes of Action of the Balanites aegyptiaca Fruit and Seed Aqueous Extracts in NA/STZ-Induced Diabetic Rats. Pharmaceutics 2022, 14 , 263. https://doi.org/10.3390/ pharmaceutics14020263

Academic Editors: Diana Marcela Aragon Novoa and Fátima Regina Mena Barreto Silva

Received: 11 December 2021

Accepted: 19 January 2022

Published: 22 January 2022

Publisher's Note: MDPI stays neutral with regard to jurisdictional claims in published maps and institutional affiliations.

Copyright: (c) 2022 by the authors. Licensee MDPI, Basel, Switzerland. This article is an open access article distributed under the terms and conditions of the Creative Commons Attribution (CC BY) license (https:// creativecommons.org/licenses/by/ $4.0 /)$.

\begin{abstract}
Diabetes mellitus (DM) is a chronic metabolic disorder that threatens human health. Medicinal plants have been a source of wide varieties of pharmacologically active constituents and used extensively as crude extracts or as pure compounds for treating various disease conditions. Thus, the aim of this study is to assess the anti-hyperglycemic and anti-hyperlipidemic effects and the modes of action of the aqueous extracts of the fruits and seeds of Balanites aegyptiaca (B. aegyptiaca) in nicotinamide (NA)/streptozotocin (STZ)-induced diabetic rats. Gas chromatography-mass spectrometry analysis indicated that 3,4,6-tri-O-methyl-d-glucose and 9,12-octadecadienoic acid (Z,Z)- were the major components of the B. aegyptiaca fruit and seed extracts, respectively. A single intraperitoneal injection of STZ (60 mg/ $\mathrm{kg}$ body weight (b.w.)) $15 \mathrm{~min}$ after intraperitoneal NA injection $(60 \mathrm{mg} / \mathrm{kg}$ b.w.) was administered to induce type $2 \mathrm{DM}$. After induction was established, the diabetic rats were treated with the B. aegyptiaca fruit and seed aqueous extracts ( $200 \mathrm{mg} / \mathrm{kg}$ b.w./day) via oral gavage for 4 weeks. As a result of the treatments with the B. aegyptiaca fruit and seed extracts, the treated diabetic-treated rats exhibited a significant improvement in the deleterious effects on oral glucose tolerance; serum insulin, and C-peptide levels; liver glycogen content; liver glucose-6-phosphatase and glycogen phosphorylase activities; serum lipid profile; serum free fatty acid level; liver lipid peroxidation; glutathione content and anti-oxidant enzyme (glutathione peroxidase, glutathione-Stransferase, and superoxide dismutase) activities; and the mRNA expression of the adipose tissue expression of the insulin receptor $\beta$-subunit. Moreover, the treatment with fruit and seed extracts also produced a remarkable improvement of the pancreatic islet architecture and integrity and increased the islet size and islet cell number. In conclusion, the B. aegyptiaca fruit and seed aqueous extracts exhibit potential anti-hyperglycemic and anti-hyperlipidemic effects, which may be mediated by increasing the serum insulin levels, decreasing insulin resistance, and enhancing the anti-oxidant defense system in diabetic rats.
\end{abstract}

Keywords: NA/STZ-induced diabetes mellitus; Balanitis aegyptiaca; fruit; seed; aqueous extracts

\section{Introduction}

Diabetes mellitus (DM) is a chronic metabolic syndrome with a number of different etiologies. It severely affects the life of patients and heightens the risk of developing other 
diseases [1]. It is characterized by abnormal carbohydrate, lipid, and protein catabolism and anabolism due to insulin resistance or hypoinsulinism [2]. The recent statistics from the International Diabetes Federation (IDF) indicated that approximately 463 million adults between the ages of 20 and 79 years have diabetes, most of whom live in poor and developing countries, and this is expected to increase to 700 million by 2045 [3]. Many factors contribute to this increasing prevalence of $\mathrm{DM}$, including population growth, urbanization, nutritional transition, physical inactivity, and dietary change $[4,5]$.

Although the existing antidiabetic synthetic drugs have several benefits, they are accompanied by many adverse side effects [6]. Thus, alternative antidiabetic agents with less or no hazardous side effects are needed [6-8]. Recently, new active medicines have been extracted from plants and have antidiabetic activity with more effectiveness than oral chemical hypoglycemic drugs used in proven therapy [9]. Medicinal plants contain various bioactive compounds that have multiple activities in insulin production, insulin action, or both [10].

Eskander and WonJun described several types of Egyptian plant and herb prescriptions for the treatment of DM, and these belong to various families [11]. Balanites aegyptiaca (L.) Delile, which belongs to the Zygophyllaceae family, is used traditionally in African countries as an antihelmintic and in the treatment of jaundice [12,13]. In Egyptian folkloric medicine, the fruit is used as an oral anti-hyperglycemic agent [14], and herbalists in the Egyptian market sell the fruits as an antidiabetic agent. Nevertheless, the quality control of such herbal products remains a great challenge. The aqueous extract of the mesocarp of the B. aegyptiaca fruit exhibited antidiabetic activities in streptozotocin (STZ)-induced diabetic mice and rats $[14,15]$, and several saponins were isolated from the mesocarp $[14,16,17]$. Moreover, the B. aegyptiaca seed kernel contains a high amount of oil and protein, which differs from one source to another [18].

Therefore, the aims of this study are to evaluate the effects of aqueous extracts of the B. aegyptiaca fruit and seed on the glycemic state and lipid profile and to indicate their probable modes of action in nicotinamide (NA)/STZ-induced diabetic rats.

\section{Materials and Methods}

\subsection{Chemicals}

NA, STZ [2-deoxy-2-(3-methyl-3nitrosoureido)-D-glycopyranoside], glucose-6-phosphate, glucose-1-phosphate, anthrone, reduced glutathione (GSH), malondialdehyde (MDA), and 1-Chloro-2,4-dinitrobenzene were purchased from Sigma-Aldrich Chemical Co., St Louis, MO, USA. All other chemicals were of analytical grade and were obtained from standard commercial supplies.

\subsection{Experimental Animals}

Male Wistar rats weighing approximately 110-140 g were used as experimental animals in the present study. The rats were housed in standard polypropylene cages and placed under a regulated room temperature of $22 \pm 2{ }^{\circ} \mathrm{C}$ and humidity of $55 \pm 5 \%$ with a 12:12 light-dark cycle. They were fed with a standard diet of known composition and water ad libitum. All animal procedures were in accordance with the ethical guidelines for the use and care of animals of the Experimental Animal Ethics Committee, Faculty of Science, Beni-Suef University, Egypt (Ethical Approval Number: BSU/FS/2015/17). All attempts were made to minimize the number and pain of used animals.

\subsection{Induction of $D M$}

After fasting for $16 \mathrm{~h}$, DM was experimentally induced in male Wistar rats via an intraperitoneal (IP) injection of $60 \mathrm{mg} \mathrm{NA} / \mathrm{kg}$ body weight (b.w.) to 16-h fasted rats before the IP injection of 60 STZ mg $/ \mathrm{kg}$ b.w. [19]. The rats were tested for serum glucose levels 10 days after STZ was injected. The overnight-fasted (10-12 h) animals were given glucose $(3 \mathrm{~g} / \mathrm{kg} \mathrm{b.w})$ via an intragastric tube. The blood samples were taken from the lateral tail vein after $2 \mathrm{~h}$ of oral administration, left to coagulate, and centrifuged. The serum glucose 
level was then measured. The experiment included rats with a serum glucose level between 180 and $300 \mathrm{mg} / \mathrm{dL}$, after $2 \mathrm{~h}$ of glucose intake, whereas the others were excluded.

\subsection{Preparation of the B. aegyptiaca Fruit and Seed Aqueous Extracts}

The B. aegyptiaca fruits and seeds were powdered using an electrical grinder. The fruit or seed powders were infused in boiled distilled water $(200 \mathrm{mg} / 10 \mathrm{~mL})$ for $15 \mathrm{~min}$. The obtained extracts were filtered pending their use via oral gavage.

\subsection{Gas Chromatography-Mass Spectrometry (GC-MS) Analysis}

Both the B. aegyptiaca fruit and seed aqueous extracts were phytochemically analyzed via GC-MS (Producer, City, Country) according to the method described in our previous publication [20].

\subsection{Experimental Design and Blood and Tissue Sampling}

The rats were allocated into four groups of six rats (Scheme 1):

\begin{tabular}{|c|c|c|}
\hline \multirow{3}{*}{ Normal } & \multicolumn{2}{|r|}{4 weeks } \\
\hline & 10 days & $5 \mathrm{~mL}$ dist. water $/ \mathrm{kg} /$ day by oral gavage \\
\hline & Citrate buffer ( $\mathrm{pH} 4$ & $.5)$; ip \\
\hline \multirow{3}{*}{ Diabetic control } & $\mathrm{NA}(60 \mathrm{mg} / \mathrm{kg} ; \mathrm{ip})$ & 4 weeks \\
\hline & $\nabla 10$ days & $5 \mathrm{~mL}$ dist. water $/ \mathrm{kg} /$ day by oral gavage \\
\hline & STZ (60 mg/g; ip) & \\
\hline \multirow{4}{*}{$\begin{array}{l}\text { Diabetic group } \\
\text { treated with the } \\
B \text {. aegyptiaca } \\
\text { fruit extract }\end{array}$} & $\mathrm{NA}(60 \mathrm{mg} / \mathrm{kg} ; \mathrm{ip})$ & 4 weeks \\
\hline & $\nabla 10$ days & $200 \mathrm{mg}$ extract $/ \mathrm{kg} /$ day by oral gavage \\
\hline & STZ (60 mg/kg; ip) & \\
\hline & $\mathrm{NA}(60 \mathrm{mg} / \mathrm{kg} ; \mathrm{ip})$ & 4 weeks \\
\hline \multirow{2}{*}{$\begin{array}{l}\text { Diabetic group } \\
\text { treated with the } \\
B \text {. aegyptiaca } \\
\text { seed extract }\end{array}$} & $\nabla 10$ days $\nabla$ & $200 \mathrm{mg}$ extract $/ \mathrm{kg} /$ day by by oral gavage \\
\hline & $\mathrm{STZ}$ (60 mg/kg; ip) & \\
\hline
\end{tabular}

Scheme 1. Schematic figure showing the experimental design and animal grouping. NA: nicotinamide; STZ: streptozotocin; B. aegptiaca: Balanites aegptiaca; and ip: intraperitoneal.

Group I (Normal group): This group was assigned as the normal control group, and rats included in this group was given distilled water daily ( $5 \mathrm{~mL} / \mathrm{kg}$ b.w./day) via oral gavage for 4 weeks.

Group II (Diabetic control): This group was assigned as the diabetic control group, and the diabetic rats within this group were given distilled water daily $(5 \mathrm{~mL} / \mathrm{kg}$ b.w./day) via oral gavage for 4 weeks.

Group III (Diabetic rats treated with the B. aegyptiaca fruit extract): This group consisted of diabetic rats that were treated daily with $B$. aegyptiaca fruit extract at a dose level of $200 \mathrm{mg} / \mathrm{kg}$ b.w./day via oral gavage for 4 weeks.

Group IV (diabetic rats treated with the B. aegyptiaca seed extract): This group consisted of diabetic rats that were treated daily with $B$. aegyptiaca seed extract at a dose level of $200 \mathrm{mg} / \mathrm{kg}$ b.w./day via oral gavage for 4 weeks.

At the day before sacrifice, oral glucose tolerance (OGT) test (OGTT) was performed by administering glucose solution $(3 \mathrm{~g} / \mathrm{kg}$ b.w.) to overnight-fasted rats via oral gavage. Successive blood samples were then obtained at 0, 30, 60, 90, and $120 \mathrm{~min}$. Blood samples were left to coagulate and centrifuged. Sera were separated via centrifugation at $3000 \mathrm{rpm}$ for $15 \mathrm{~min}$, and the serum glucose levels were determined. One day after the end of the experiment, blood samples were collected from the jugular vein under diethyl ether inhalation. Moreover, the rats were euthanized and dissected for the excision of various organs. 


\subsection{Blood Sampling and Tissue Sampling}

The blood obtained from the jugular vein of each rat was left to coagulate at room temperature. Serum was separated for $15 \mathrm{~min}$ via centrifugation at $3000 \mathrm{rpm}$ and stored at $-20{ }^{\circ} \mathrm{C}$ pending its use for the determination of insulin and C-peptide levels as well as other biochemical parameters. The rats were rapidly dissected. Visceral adipose tissues were excised and kept at $-70{ }^{\circ} \mathrm{C}$ until use for ribonucleic acid (RNA) extraction and the detection of the messenger RNA (mRNA) of adiponectin and resistin via reverse transcription-polymerase chain reaction (RT-PCR). The liver was excised for the determination of oxidative stress parameters and glycogen content and glycogen metabolizing enzymes. The pancreas was also excised for histological investigation.

\subsection{Biochemical Analysis}

The serum glucose levels were measured using the reagent kits purchased from Spinreact Company (Spain) using the method of Trinder et al. [21]. The serum insulin level was measured using sandwich enzyme-linked immunosorbent assay (ELISA) using kits purchased from Linco Research, USA, in accordance with the manufacturer's instructions. Similarly, the serum C-peptide level was measured using the ELISA kits purchased from Linco Research, USA, in accordance with the manufacturer's instructions. Homeostatic model assessment (HOMA)-insulin resistance (IR), HOMA-insulin sensitivity (IS) [22], and HOMA- $\beta$ cell function [23] were calculated using the following formulas, respectively:

HOMA-IR $=($ fasting insulin $[\mu \mathrm{IU} / \mathrm{mL}] \times$ fasting glucose $[\mathrm{mg} / \mathrm{dL}]) / 405$

HOMA-IS $=10,000 /($ fasting insulin $[\mu \mathrm{IU} / \mathrm{mL}] \times$ fasting glucose $[\mathrm{mg} / \mathrm{dL}])$

HOMA- $\beta$ cell function $=(20 \times$ fasting insulin $[\mu \mathrm{IU} / \mathrm{mL}]) /($ fasting glucose $[\mathrm{mg} / \mathrm{dL} / 18]-3.5)$.

The liver glycogen content was measured using the method of Seifter et al. [24]. The liver glucose-6-phosphatase and glycogen phosphorylase activities were measured using laboratory-prepared chemicals and the methods of Begum et al. [25] and Stallman and Hers, respectively [26]. The serum cholesterol level was assayed using the method of Allain et al. and the reagent kits purchased from Spinreact Company (Spain) [27].

The serum triglyceride level was determined using the reagent kit purchased from Reactivos Spinreact Company (Girona, Spain) and Fossati and Prencipe's method [28]. The serum high density lipoprotein (HDL)-cholesterol level was measured using the method of Allain et al. (1974) and the reagent kit obtained from Spinreact Company, Spain [27]. The serum low density lipoprotein (LDL) cholesterol level was calculated using the formula of Friendewald et al. [29]:

$$
\text { LDL cholesterol }=\text { total cholesterol }- \text { triglycerides } / 5-\text { HDL cholesterol }
$$

Serum very low density lipoprotein (vLDL)-cholesterol was calculated using Norbert's formula [30]:

$$
\text { vLDL cholesterol conc. }=\text { triglycerides } / 5
$$

The serum free fatty acid (FFA) level was determined using Duncombe's method [31].

\subsection{RNA Isolation and RT-PCR}

RNA was isolated from visceral adipose tissue using the GeneJet RNA purification kit produced by Thermo Fisher Scientific Inc., Branchburg, NJ 08876, USA, according to the procedures of Chomzynski and Sacchi [32] and Boom et al. [33]. The isolated RNA was quantified and qualified [34,35]. Thermo Scientific Verso 1-Step RTPCR ReddyMix was used to produce cloned DNA that was amplified in the presence of specific forward and reverse primers using a Techne thermal cycler, Cole-Parmer, IL 60061, USA [35]. The primer pair sequences for the insulin receptor $\beta$-subunit were F: 5'CTGGAGAACTGCTCGGTCATT3' and R: 5'GGCCA-TAGACACGGAAAAGAAG3' [36], 
and those for $\beta$-actin re F: 5'TCACCCTGAAGTACCCCATGGAG3' and R: 5'TTGGCCTTGG GGTTCAGGGGG3' $[37,38]$.

\subsection{Determination of Oxidative Stress and Anti-Oxidant Defense Parameters}

The glutathione content (GSH) in the liver was determined [39]. Moreover, glutathioneS-transferase (GST) activity in the liver was measured using Mannervik and Gutenberg's method [40]. The liver glutathione peroxidase (GPx) activity was determined using the method of Matkovics et al. [41]. The superoxide dismutase (SOD) and lipid peroxidation (LPO) were determined using the methods of Marklund and Marklund [42] and Preuss et al. (1998), respectively [43].

\subsection{Histological Investigation}

The pancreas from each rat was rapidly excised after dissection and then fixed in 10\% neutral buffered formalin for $24 \mathrm{~h}$. The organs were routinely processed and sectioned at a thickness of 4 to $5 \mu \mathrm{m}$. The sections of the pancreas were stained with hematoxylin and $\operatorname{eosin}[44,45]$.

\subsection{Statistical Analysis}

The results were analyzed using the PC-STAT Program [46]. One-way analysis of variance (ANOVA) was followed by the least significant difference (LSD) test to compare various groups. Data were described as the mean $\pm \mathrm{SE}$. A $p$ value of $>0.05$ was considered nonsignificantly different, whereas $p$ values of $<0.05$ and $<0.01$ were considered significant and highly significant, respectively.

\section{Results}

\subsection{GC-MS Analysis}

The GC-MS analysis of the B. aegyptiaca fruit and seed extracts showed the presence of several phytocomponents. Tables 1 and 2 and Figures 1 and 2 show the identified phytocomponents with their retention time, which was expressed as the peak area $\%$. In the fruit extract, compounds 3,4,6-tri-O-methyl-d-glucose (52.55\%) and triethylphosphine $(9.31 \%)$ were the most abundant. Conversely, in the seed extract, compounds 9,12-octadecadienoic acid (Z,Z)- (38.27\%), 8-dodecen-1-ol, (Z)- (15.09\%), 2,3-dihydroxypropyl ester (11.47\%), and H-cyclopenta [b]quinoxaline-1,2,3trione (11.39\%) were the most abundant.

Table 1. Chemical groups and compounds present in the B. aegyptiaca fruit aqueous extract.

\begin{tabular}{cccc}
\hline Number & (RT) Retention Time & Compound Name & Area\% (Higher than 1\%) \\
\hline 1 & 2.123 & Hydrazine, 1,1-dimethyl- & 4.31 \\
2 & 3.008 & Butanal, 2-methyl- & 3.04 \\
3 & 3.043 & Butanal, 2-methyl- & 1.89 \\
4 & 3.363 & Propanoic acid, propyl ester & 3.41 \\
5 & 3.907 & Glyceraldehyde & 5.39 \\
6 & 4.250 & 2-Furanmethanol & 2.55 \\
7 & 4.645 & Isopropyl isothiocyanate & 2.64 \\
8 & 4.889 & Triethylphosphine & 9.31 \\
9 & 9.454 & 2,4(3H,5H)-Furandione & 1.46 \\
10 & 9.744 & Pyridine, 4-chloro-2,6-dimethyl- & 0.96 \\
11 & 18.561 & 3,4,6-Tri-O-methyl-d-glucose & 52.55 \\
13 & 21.667 & Perhydrohistrionicotoxin-2-thione, & 2.07 \\
\end{tabular}


Table 2. Chemical groups and compounds present in the B. aegyptiaca seed aqueous extract.

\begin{tabular}{cccc}
\hline Number & Retention Time & Compound Name & Area\% (Higher than 1\%) \\
\hline 1 & 4.263 & Butane, 2-methyl- & 1.67 \\
2 & 20.538 & $-3,4,6$ Tri-O-methyl-d-glucose & 2.59 \\
3 & 24.018 & H-Cyclopenta & 11.39 \\
4 & 25.505 & [b]quinoxaline-1,2,3trione & 2.47 \\
5 & 25.568 & -9, 2Octadecadienoic acid (Z,Z)- & 1.62 \\
6 & 26.152 & 13-Octadecenoic acid, methyl ester & 38.27 \\
7 & 26.192 & 9,12-Octadecadienoic acid (Z,Z)- & 15.09 \\
8 & 26.281 & 8-Dodecen-1-ol, (Z)- & 11.47 \\
9 & 26.339 & 9,12-Octadecadienoic acid (Z,Z)-, & 6.06 \\
10 & 26.371 & 2,3-dihydroxypropyl ester & 6.79 \\
\end{tabular}

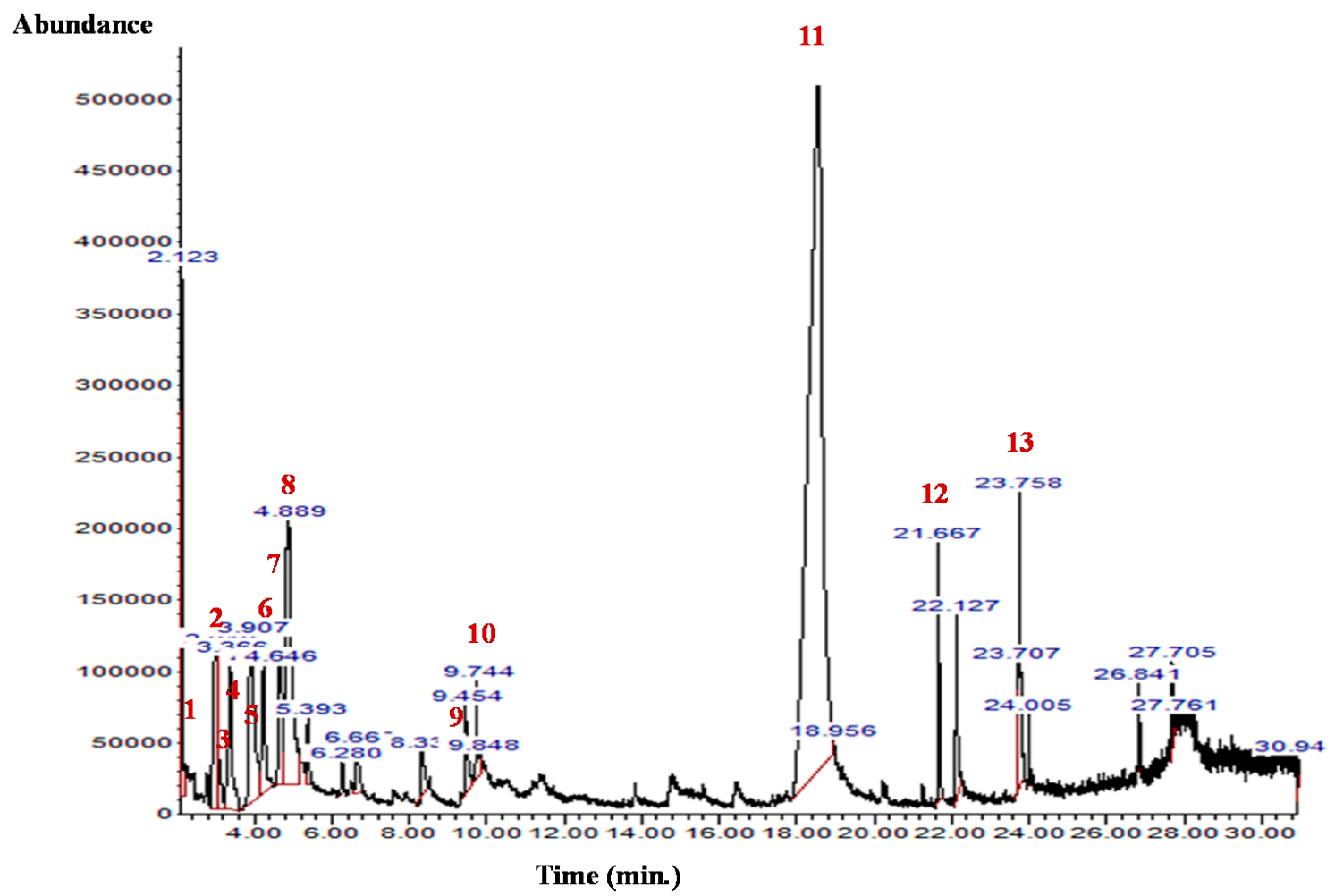

Figure 1. GC-MS chromatogram of the B. aegyptiaca fruit aqueous extract. 1: Hydrazine, 1,1-dimethyl-; 2 and 3: Butanal, 2-methyl-; 4: Propanoic acid, propyl ester; 5: Glyceraldehyde; 6: 2-Furanmethanol; 7: Isopropyl isothiocyanate; 8: Triethylphosphine; 9: 2,4(3H,5H)-Furandione; 10: Pyridine, 4-chloro2,6-dimethyl-; 11: 3,4,6-Tri-O-methyl-d-glucose; 12: Perhydrohistrionicotoxin-2-thione, 2-depentyl-; and 13: Propyl 11,12-methylene-octadecanoate.

\subsection{Effects on $O G T$}

The OGT curve of the diabetic rats exhibited a significant $(p<0.01$; LSD) elevation at all tested periods $(0,30,60,90$, and $120 \mathrm{~min})$ after oral glucose intake compared with that of normal animals. The oral administration of B. aegyptiaca fruit and seed extracts to diabetic rats induced a potential amelioration of elevated values at all tested points of the OGT curve. However, the seed extract was more potent at 30 and $60 \mathrm{~min}$ after oral glucose intake (Figure 3). The F-probability of OGTT data indicated that the effect between groups was very highly significant $(p<0.01)$. 


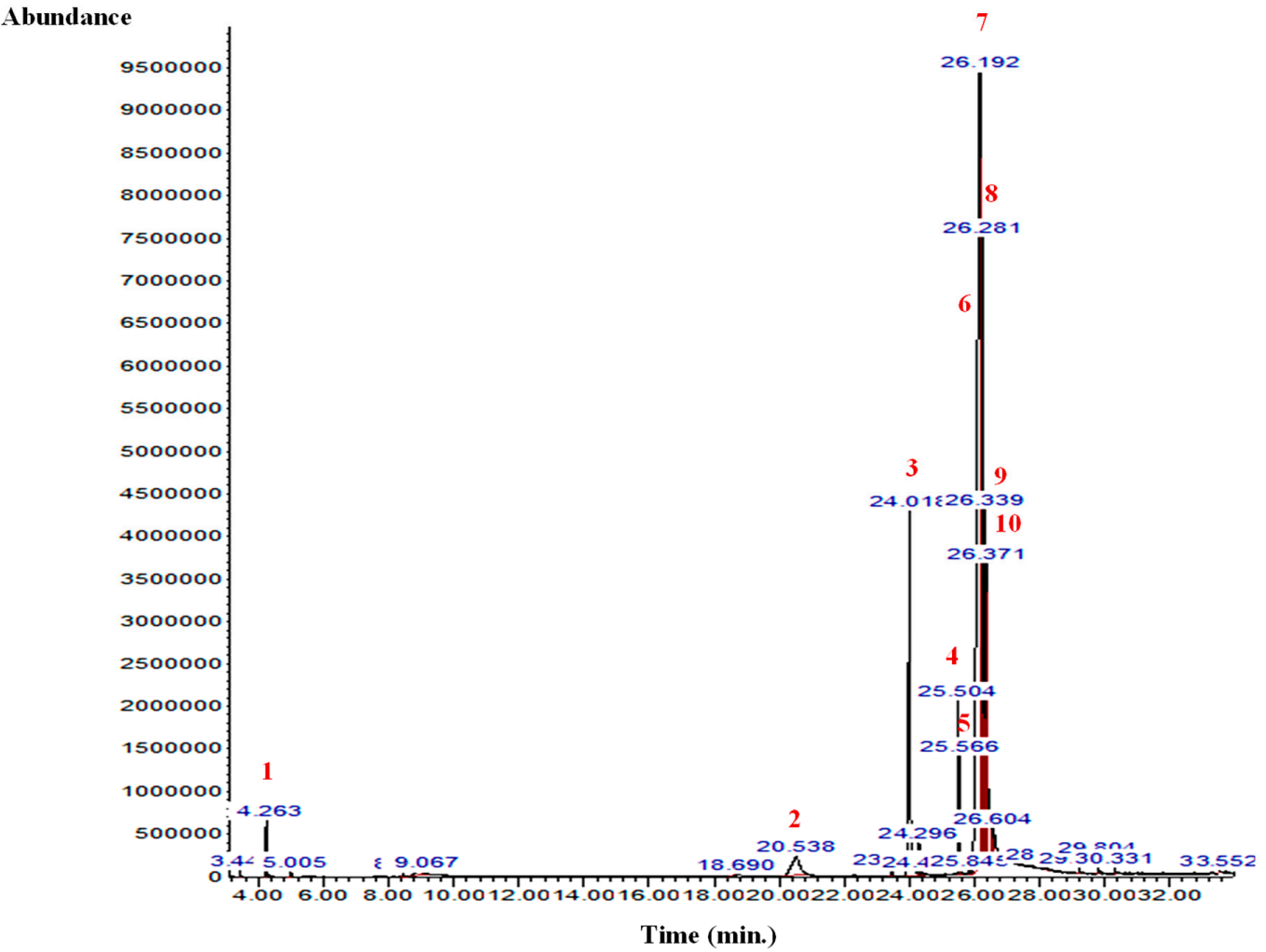

Figure 2. GC-MS chromatogram of the B. aegyptiaca seed aqueous extract. 1: Butane, 2-methyl-; 2: 3,4,6-Tri-O-methyl-d-glucose; 3: 3,4,6-Tri-O-methyl-d-glucose; 4: 9,12-Octadecadienoic acid (Z,Z)-; 5: 13-Octadecenoic acid, methyl ester; 6: 9,12-Octadecadienoic acid (Z,Z)-; 7: 8-Dodecen-1-ol, (Z)-; 8: 9,12-Octadecadienoic acid (Z,Z)-, 2,3-dihydroxypropyl ester; 9: Octadec-9-enoic acid; and 10: Benzoic acid, 4-(4-hydroxybenzylidenamino)-, propyl ester.

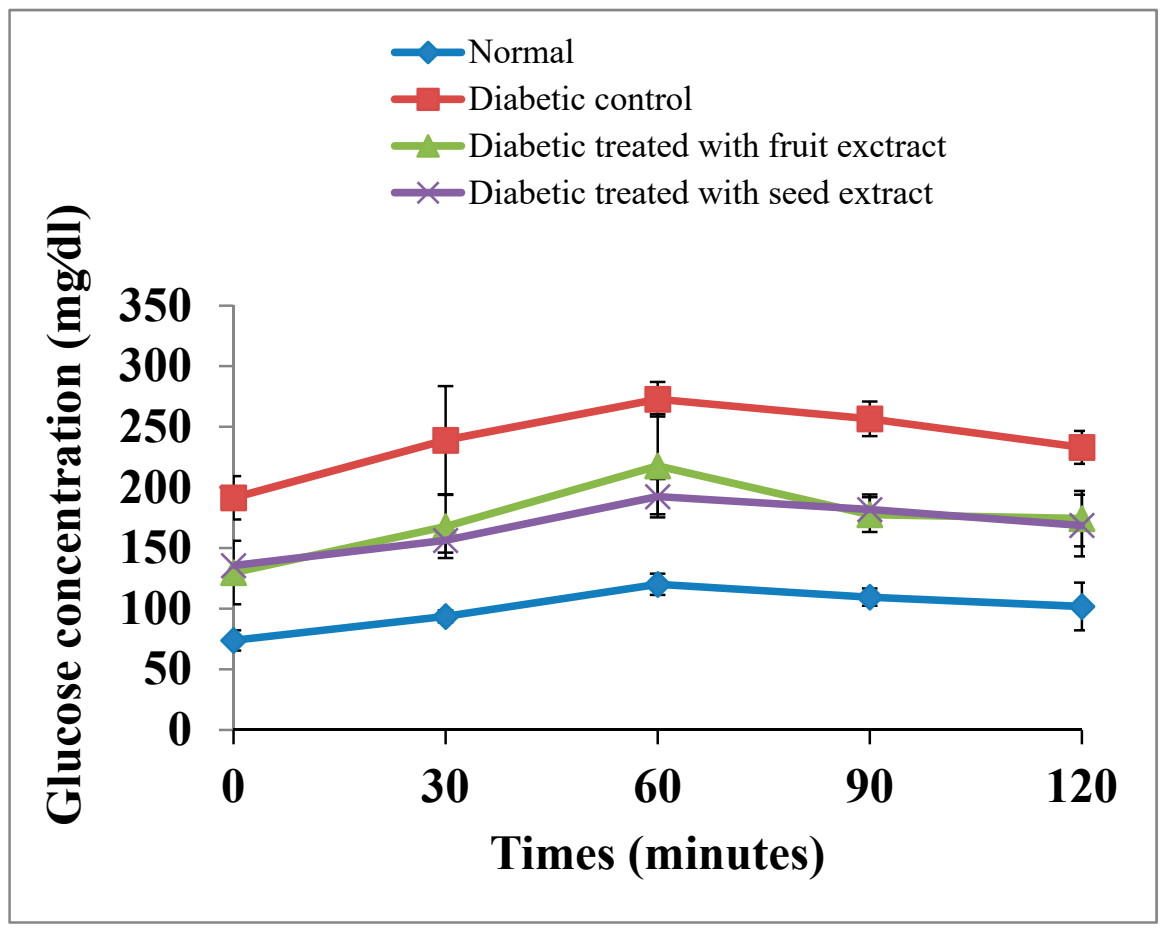

Figure 3. Effects of the B. aegyptiaca fruit and seed extracts on OGTT in NA/STZ-induced diabetic rats. 


\subsection{Effects on Serum Insulin and C-Peptide Levels}

As indicated in Table 3, the diabetic rats showed a highly significant decrease $(p<0.01$; LSD) in the insulin and C-peptide levels in serum. The treatments of the diabetic rats with the fruit and seed extracts caused a highly significant increase $(p<0.01$; LSD) in these lowered levels. The diabetic rats treated with the B. aegyptiaca fruit extract exhibited no significant effects on the insulin and C-peptide levels in comparison with the diabetic rats treated with the B. aegyptiaca seed extract. However, the effects of the fruit extract was more potent in increasing the serum insulin levels. The F-probability indicated that the general effect between groups was very highly significant $(p<0.01)$.

Table 3. Effects of the B. aegyptiaca fruit and seed extracts on the serum insulin and C-peptide levels in NA/STZ-induced diabetic rats.

\begin{tabular}{|c|c|c|}
\hline $\begin{array}{ll}\text { Group } & \text { Parameter } \\
\end{array}$ & Insulin $(\mu \mathrm{IU} / \mathrm{mL})$ & C-Peptide (pg/mL) \\
\hline Normal & $2.56 \pm 0.51^{a}$ & $4.7 \pm 0.13^{a}$ \\
\hline Diabetic control & $1.00 \pm 0.78^{c}$ & $1.19 \pm 0.13^{c}$ \\
\hline Diabetic treated with fruit extract & $1.71 \pm 0.11^{b}$ & $3.47 \pm 0.44^{b}$ \\
\hline Diabetic treated with seed extract & $1.56 \pm 0.11^{b}$ & $3.50 \pm 0.22^{b}$ \\
\hline
\end{tabular}

- Data were expressed as the mean \pm SE. The number of animals in each group was six. - Means, which have different superscript symbols $(\mathrm{a}, \mathrm{b}$, and $\mathrm{c})$, were significantly different at $p<0.05$.

\subsection{Effect on HOMA-IR Cell Function, HOMA-IS, and HOMA- $\beta$ Cell Function}

In diabetic rats, the HOMA-IS and HOMA- $\beta$ cell functions were highly significantly $(p<0.01$; LSD) decreased, whereas HOMA-IR was highly significantly $(p<0.01$; LSD) increased. The treatment of diabetic rats with $B$. aegyptiaca fruit and seed extracts induced a highly significant increase in HOMA- $\beta$ cell function and HOMA-IS. In contrast, HOMA-IR was highly significantly decreased after the treatments with the B. aegyptiaca fruit and seed extracts.

Although the effects of the B. aegyptiaca fruit and seed extracts on HOMA-IR and HOMA-IS were more or less similar, the effects of the fruit extract on HOMA- $\beta$ cell function was more potent than that of the seed extract (Table 4). One-way ANOVA revealed that the effect between groups on the HOMA-IR, HOMA-IS, and HOMA- $\beta$ cell function was very highly significant $(p<0.01 ;$ F-probability).

Table 4. Effects of the B. aegyptiaca fruit and seed extracts on HOMA-IR cell function, HOMA-IS, and HOMA- $\beta$ cell function in NA/STZ-induced diabetic rats.

\begin{tabular}{|c|c|c|c|}
\hline $\begin{array}{ll}\text { Group } & \text { Parameter } \\
\end{array}$ & HOMA-IR & HOMA-IS & $\begin{array}{l}\text { HOMA- } \beta \\
\text { Cell Function }\end{array}$ \\
\hline Normal & $0.37 \pm 0.03^{c}$ & $55.48 \pm 2.23^{a}$ & $55.50 \pm 1.42^{\mathrm{a}}$ \\
\hline Diabetic control & $0.51 \pm 0.04^{\mathrm{a}}$ & $45.50 \pm 0.66^{b}$ & $2.71 \pm 0.17^{d}$ \\
\hline Diabetic treated with fruit extract & $0.40 \pm 0.03^{b}$ & $55.00 \pm 1.23^{a}$ & $11.20 \pm 0.90^{b}$ \\
\hline Diabetic treated with seed extract & $0.45 \pm 0.03^{b}$ & $53.33 \pm 1.03^{\mathrm{a}}$ & $7.80 \pm 0.39^{c}$ \\
\hline
\end{tabular}

different superscript symbols ( $\mathrm{a}, \mathrm{b}, \mathrm{c}$, and $\mathrm{d} \mathrm{c}$ ), were significantly different at $p<0.05$.

\subsection{Effects on Liver Glycogen Content and Glucose-6-phospatase and Glycogen Phosphorylase Activities}

The diabetic rats exhibited a highly significant $(p<0.01$; LSD) depletion in liver glycogen content and a highly significant $(p<0.01$; LSD) elevation in liver glucose-6phosphatase and glycogen phosphorylase activities. The treatments with the B. aegyptiaca fruit and seed extracts highly significantly improved $(p<0.01$; LSD) the reduced liver glycogen content of the diabetic rats and the elevated glucose-6-phosphatase and glycogen 
phosphorylase activities (Table 5). One-way ANOVA revealed that the effect between groups on liver glycogen content and glucose-6-phosphatase and glycogen phosphorylase activities was very highly significant ( $p<0.01$; F-probability).

Table 5. Effects of the B. aegyptiaca fruit and seed extracts on liver glycogen content and glucose-6phosphatase and glycogen phosphorylase activities in NA/STZ-induced diabetic rats.

\begin{tabular}{|c|c|c|c|}
\hline Parameter & $\begin{array}{c}\text { Liver Glycogen } \\
\text { (mg P liberated/g } \\
\text { Tissue/h) }\end{array}$ & $\begin{array}{c}\text { Glucose-6- } \\
\text { phosphatase (mg Pi } \\
\text { liberated/g Tissue/h) }\end{array}$ & $\begin{array}{c}\text { Glycogen } \\
\text { Phosphorylase (mg Pi } \\
\text { liberated/g Tissue/h) }\end{array}$ \\
\hline Normal & $54.55 \pm 3.60^{\mathrm{a}}$ & $25.79 \pm 1.53^{b}$ & $22.78 \pm 3.09^{b}$ \\
\hline Diabetic control & $8.10 \pm 1.66^{b}$ & $67.42 \pm 3.38^{a}$ & $41.85 \pm 6.08^{a}$ \\
\hline Diabetic treated with fruit extract & $42.75 \pm 2.91^{a}$ & $28.02 \pm 0.41^{b}$ & $25.45 \pm 4.95^{b}$ \\
\hline Diabetic treated with seed extract & $50.51 \pm 3.60^{\mathrm{a}}$ & $31.45 \pm 2.28^{b}$ & $15.22 \pm 2.20^{b}$ \\
\hline
\end{tabular}

- Data were expressed as the mean \pm SE. The number of animals in each group was six. - Means, which have different superscript symbols $(\mathrm{a}, \mathrm{b}$, and $\mathrm{c})$, were significantly different at $p<0.05$.

\subsection{Effects on Serum Lipid Profile}

The total cholesterol, triglycerides, LDL-cholesterol, vLDL- cholesterol, and FFA levels in serum exhibited a highly significant elevation $(p<0.01$; LSD) in diabetic rats compared with those in the normal group. The treatment of diabetic rats with the B. aegyptiaca fruit and seed extracts produced a highly significant improvement in the altered lipid profile in the serum. Moreover, the HDL- cholesterol level was affected in an inverse pattern, as it was highly significantly decreased ( $p<0.01$; LSD) in diabetic rats.

Conversely, the treatment with the fruit extract induced a significant increase $(p<0.01$; LSD) compared with the diabetic control, whereas the treatment with the seed extract had no significant effect ( $p>0.05$; LSD) (Table 6). The seed extract was more effective in decreasing the elevated total cholesterol and triglyceride levels in diabetic rats than the fruit extract, whereas the fruit extract was more potent in decreasing the elevated LDLcholesterol, vLDL-cholesterol, and FFA levels and increasing the lowered HDL-cholesterol level (Table 6). The F-probability revealed that the effect on serum lipid profile between groups was very highly significant $(p<0.01)$.

Table 6. Effects of the B. aegyptiaca fruit and seed extracts on serum lipid profile and FFA level in NA/STZ-induced diabetic rats.

\begin{tabular}{|c|c|c|c|c|c|c|}
\hline Parameter & $\begin{array}{c}\text { Total } \\
\text { Cholesterol } \\
(\mathrm{mg} / \mathrm{dL})\end{array}$ & $\begin{array}{l}\text { Triglycerides } \\
\text { (mg/dL) }\end{array}$ & $\begin{array}{c}\text { LDL- } \\
\text { Cholesterol } \\
(\mathrm{mg} / \mathrm{dL})\end{array}$ & $\begin{array}{c}\text { HDL- } \\
\text { Cholesterol } \\
(\mathrm{mg} / \mathrm{dL})\end{array}$ & $\begin{array}{c}\text { vLDL- } \\
\text { Cholesterol } \\
\text { (mg/dL) }\end{array}$ & FFAs (mg/dL) \\
\hline Normal & $42.70 \pm 1.34^{c}$ & $35.66 \pm 2.25^{c}$ & $5.10 \pm 2.10^{c}$ & $31.30 \pm 2.30^{a}$ & $7.11 \pm 0.33^{c}$ & $5.10 \pm 0.86^{b}$ \\
\hline Diabetic control & $79.40 \pm 9.48^{a}$ & $80.25 \pm 15.30^{a}$ & $37.48 \pm 6.03^{a}$ & $24.80 \pm 2.80^{b}$ & $16.08 \pm 3.00^{a}$ & $18.70 \pm 2.7^{a}$ \\
\hline Diabetic treated with fruit extract & $59.70 \pm 9.30^{b}$ & $53.70 \pm 2.83^{b}$ & $13.18 \pm 4.76^{b}$ & $31.00 \pm 2.10^{a}$ & $8.11 \pm 1.05^{c}$ & $5.10 \pm 0.70^{b}$ \\
\hline Diabetic treated with seed extract & $51.80 \pm 9.70 \mathrm{bc}$ & $41.25 \pm 5.34^{c}$ & $15.94 \pm 7.90^{b}$ & $27.10 \pm 0.80^{b}$ & $10.71 \pm 0.056^{b}$ & $6.75 \pm 1.80^{b}$ \\
\hline
\end{tabular}

- Data were expressed as the mean \pm SE. The number of animals in each group was six. - Means, which have different superscript symbols $(\mathrm{a}, \mathrm{b}$, and $\mathrm{c})$, were significantly different at $p<0.05$.

\subsection{Effect on Insulin Receptor $\beta$-Subunit}

The densitometric analysis of the electrophoretogram showed a highly significant $(p<0.01$; LSD) decrease in the mRNA expression of the adipose tissue insulin receptor $\beta$-subunit in diabetic rats compared with that in the normal group. The treatment of diabetic rats with the B. aegyptiaca fruit extract produced a highly significant $(p<0.01$; LSD) amelioration of the insulin receptor $\beta$-subunit mRNA expression (Figure 4 ), whereas the treatment with the B. aegyptiaca seed extract did not show a significant effect $(p>0.05$; LSD). One-ANOVA indicated that the effect between groups on the mRNA expression of insulin receptor $\beta$-subunit was highly significant $(p<0.01$; F-probability). 


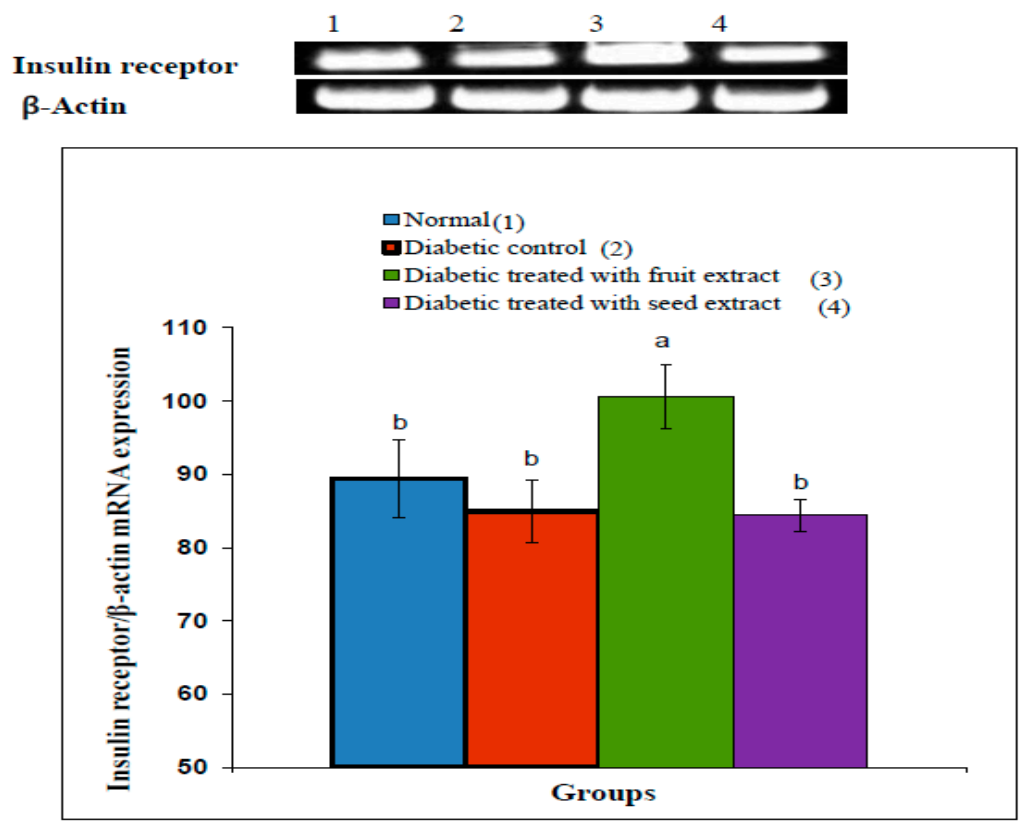

Figure 4. Effects of the B. aegyptiaca fruit and seed extracts on the adipose mRNA expression of insulin receptor $\beta$-subunit relative to $\beta$-actin in NA/STZ-administered rats. The means, which have different superscript symbols (a and $b$ ), were significantly different at $p<0.05$. The number of detected samples in each group was three.

\subsection{Effect on Oxidative Stress and Anti-Oxidant Defense Parameters}

The liver LPO exhibited a highly significant $(p<0.01$; LSD) increase in diabetic rats compared with that in normal rats. The treatment with the B. aegyptiaca fruit and seed extracts in diabetic rats resulted in a highly significant $(p<0.01$; LSD) amelioration in LPO; the effects of the fruit extract were the most potent.

The GSH content as well as the GPx, GST, and SOD activities showed a highly significant $(p<0.01$; LSD) decline in diabetic control rats compared with those in the normal rats. The treatments with the B. aegyptiaca fruit and seed extracts successfully improved the GSH content and GPx, GST ( $p<0.01$; LSD), and SOD activities ( $p<0.05$; LSD) (Table 7). While the effects of the fruit and seed extracts on GSH content and anti-oxidant enzyme activities were more or less similar, the seed extract was more potent in decreasing the elevated LPO.

Table 7. Effects of the B. aegyptiaca fruit and seed extracts on liver LPO, GSH content, and GPx, GST, and SOD activities in NASTZ-induced diabetic rats.

\begin{tabular}{|c|c|c|c|c|c|}
\hline Parameter & $\begin{array}{c}\text { LPO } \\
\text { (nmole MDA/100 mg } \\
\text { Tissue/h) } \\
\end{array}$ & $\begin{array}{c}\text { GSH } \\
\text { (nmole/100 mg } \\
\text { Tissue) } \\
\end{array}$ & $\begin{array}{c}\text { GPx } \\
\text { (mU/100 mg } \\
\text { Tissue) }\end{array}$ & $\begin{array}{c}\text { GST } \\
\text { (U/100mg Tissue) }\end{array}$ & $\begin{array}{c}\text { SOD } \\
\text { (U/g Tissue) }\end{array}$ \\
\hline Normal & $67.17 \pm 1.25^{b c}$ & $13.30 \pm 1.63^{\mathrm{a}}$ & $42.60 \pm 5.1^{\mathrm{a}}$ & $12.65 \pm 3.6^{\mathrm{b}}$ & $16.78 \pm 1.59^{\mathrm{a}}$ \\
\hline Diabetic control & $111.39 \pm 7.57^{\mathrm{a}}$ & $6.10 \pm 1.60^{c}$ & $17.20 \pm 5.1^{\mathrm{c}}$ & $6.57 \pm 1.65^{c}$ & $10.31 \pm 1.58^{c}$ \\
\hline Diabetic treated with fruit extract & $68.75 \pm 3.80^{b}$ & $12.10 \pm 1.54^{\mathrm{ab}}$ & $30.80 \pm 4.6^{\mathrm{b}}$ & $16.54 \pm 0.86^{\mathrm{a}}$ & $13.46 \pm 2.55^{b}$ \\
\hline Diabetic treated with seed extract & $52.95 \pm 5.821^{c}$ & $11.20 \pm 1.5^{\mathrm{b}}$ & $31.00 \pm 2.5^{b}$ & $16.43 \pm 0.85^{\mathrm{a}}$ & $13.26 \pm 2.08^{b}$ \\
\hline
\end{tabular}

- Data were expressed as the mean \pm SE. The number of animals in each group was six. - Means, which have different superscript symbols $(\mathrm{a}, \mathrm{b}$, and $\mathrm{c})$, were significantly different at $p<0.05$.

The F-probability indicated that the effect on the liver LPO, GSH content, and GPx, GST, and SOD activities between groups was very highly significant $(p<0.01$; F-probability)

\subsection{Histological Changes in the Pancreas}

The histopathological examination of the control pancreas sections showed closely packed lobules of the pancreatic acini. The islet of Langerhans is composed of numerous 
compactly arranged cells (alpha, beta, and delta cells) occurring as dense cords (Figure 5; Photomicrographs A and B). The diabetic control revealed the histopathological changes of endocrine portions represented by a marked decrease in the size of the islets of pancreas (pancreatic shrinkage) and decreased number of the cells.

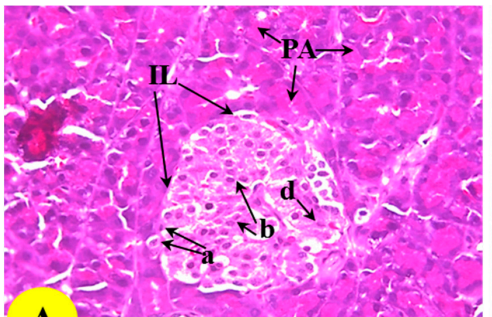

\section{A}
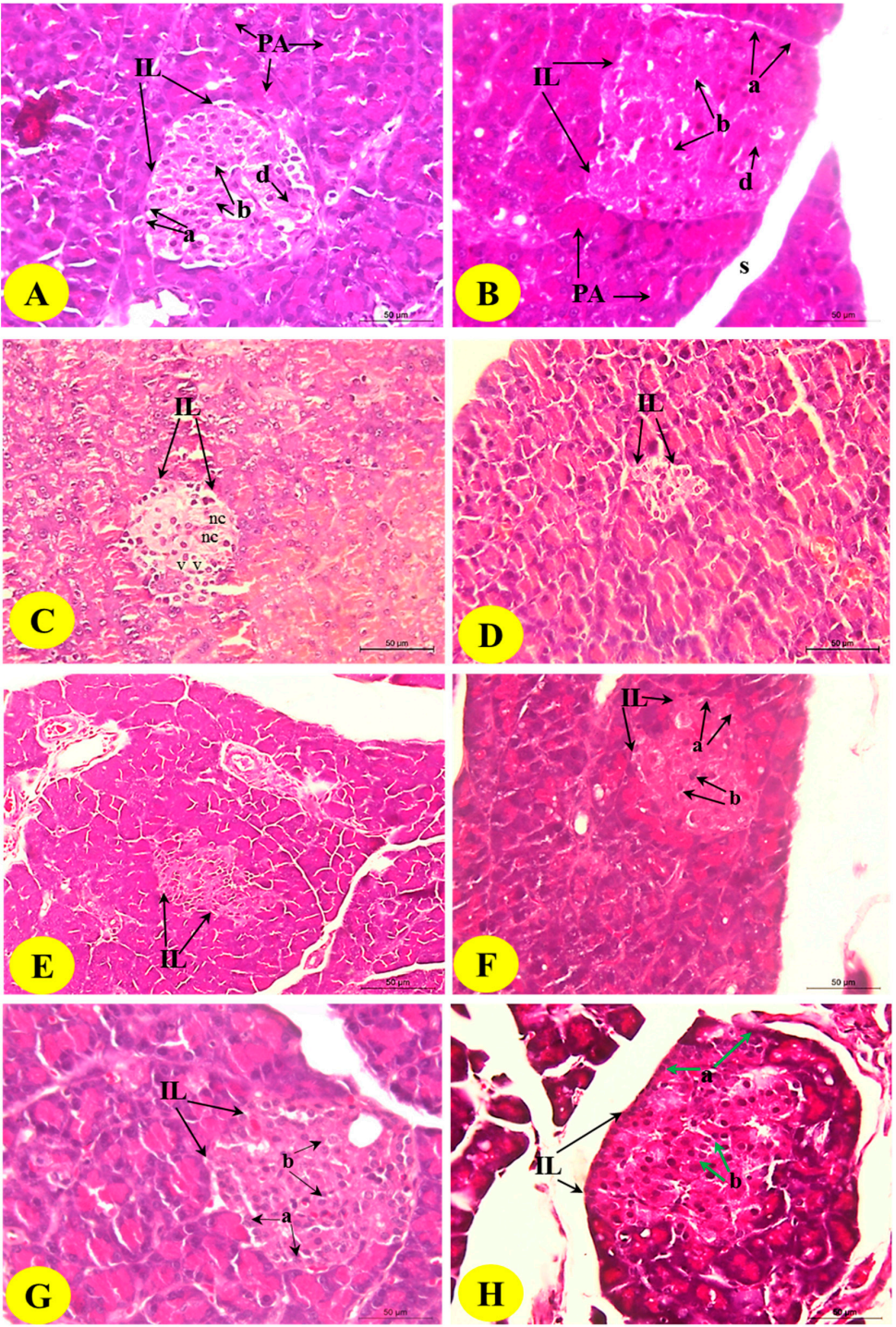

Figure 5. Photomicrographs of the H\&E-stained pancreas of the normal (A,B), diabetic control (C,D), and diabetic rats treated with the B. aegyptiaca fruit $(\mathbf{E}, \mathbf{F})$ and seed extracts $(\mathbf{G}, \mathbf{H})$. Photomicrographs $A$ and B show normal pancreatic lobules consisting of pancreatic acini and intact islets of Langerhans (IL) with alpha (a), beta (b), and delta cells. Photomicrographs $C$ and D show the islets of Langerhans with the reduced size and smaller number of the cells; the islets exhibited necrosis (nc) and vacuolations (v) (H\&E stain: Scale bar $=50 \mu \mathrm{m})$. Photomicrographs E-H show considerable improvements in the islets of Langerhans with a greater increase in the islet size and the number of islet cells.

The islets also exhibited cytoplasmic vacuolations (v) and necrosis (nc) (Figure 5; Photomicrographs $C$ and $D$ ). The islets of Langerhans exhibited nearly normal and organized architecture, and the necrotic and degenerative changes were markedly improved in rats treated with the B. aegyptiaca fruit (Figure 5; Photomicrographs E and F) and seed extracts (Figure 5; Photomicrographs $\mathrm{G}$ and $\mathrm{H}$ ) compared with those in the diabetic control rats; the seed extract was found to be the most potent. 


\section{Discussion}

DM is a group of metabolic diseases characterized by chronic hyperglycemia due to defects in insulin secretion, insulin action, or both [47]. STZ is known for its selective pancreatic islet $\beta$-cell cytotoxicity and has been frequently used to induce DM in animals. NA/STZ-induced DM is selected to be a model of type 2 DM (T2DM) to assess the effects of the B. aegyptiaca fruit and seed aqueous extracts. In this model, when NA is injected prior to the administration of STZ, the severity of DM will be reduced to a certain extent, leading to a T2DM-like condition with deteriorated IS [20,35,48-50].

Several traditional medicines have been discovered for DM. Isolated substances and extracts isolated from various natural resources particularly plants have always been a rich arsenal for the control and treatment of DM problems and complications [9]. Plants have rich sources of antidiabetic as well as anti-hyperlipidemic and anti-oxidant substances, such as flavonoids, amino acids, gallotannins, and many other related polyphenols [51]. B. aegyptiaca is a plant widely used as a hypoglycemic agent in Egyptian folkloric medicine [15]. However, only few studies have investigated the antidiabetic effects and the mechanisms of action of B. aegyptiaca, especially its seeds.

In the present study, GC-MS data presented in Tables 1 and 2 revealed the presence of several active ingredients. In the B. aegyptiaca fruit aqueous extract, 3,4,6-tri-O-methyl$\mathrm{d}$-glucose $(52.55 \%)$ and triethylphosphine $(9.31 \%)$ were the most abundant, whereas in the seed aqueous extract, 9,12-octadecadienoic acid (Z,Z)- (38.27\%), 8-dodecen-1-ol, (Z)(15.09\%), 2,3-dihydroxypropyl ester (11.47\%), and $\mathrm{H}$-cyclopenta [b]quinoxaline-1,2,3trione $(11.39 \%)$ were the major components.

Many of the constituting ingredients of the B. aegyptiaca fruit and seed aqueous extracts exhibit many biological activities. Of these, 9,12-octadecadienoic acid (Z,Z)have anti-inflammatory, hepatoprotective, cancer preventive, and hypocholesterolemic effects $[20,52,53]$. The derivative 9-octadecenoic acid was reported to have antitumor and anti-inflammatory activities [53]. Isothiocyanates have been demonstrated to have both anti-inflammatory and antioxidant activities [54].

OGTT is a well-known and common assay used to determine the anti-hyperglycemic activity of antidiabetic agents [55]. OGTT is considered the gold standard test for the diagnosis of DM by the World Health Organization [56]. The data in the present study revealed a marked increase in the serum glucose levels of the diabetic groups compared with those of the normal rats. These findings are consistent with those of Akhani et al. [57], Ahmed [58], Schaalan et al. [59], Ahmed et al. [60], Ahmed et al. [61], and Ali et al. [62].

The increase in glucose level may be due to the decreased glucose consumption in the peripheral, muscle, and adipose tissues [63] and increased glycogen breakdown [64], gluconeogenesis, and production of hepatic glucose [65]. Furthermore, Powers confirmed that IR in T2DM induces an increase in blood glucose because of the same causes [66]. In the present study, the treatment of diabetic rats with the B. aegyptiaca fruit or seed extracts caused a potential improvement in OGT. The decrease in the elevated serum glucose levels is in accordance with the results of Zaahkouk et al. [67], Helal et al. [68], and Al-Malki et al. [69] who verified the anti-hyperglycemic effects of the B. aegyptiaca fruit.

The ameliorative effects of the B. aegyptiaca extracts may be associated with insulinomimetic activities [70], stimulation and potentiation of insulin secretion, increased affinity of insulin receptors [71], improved concentration of hepatic glycogen, accelerated glucose metabolism, reduced production of intestinal glucosidase, and decreased gluconeogenesis of the liver [15]. These actions may be attributed to the active constituting ingredients found in the B. aegyptiaca fruit and seed extracts. In this regard, a previous publication found that B. aegyptiaca may contain interketones, organic constituents, rutin, and oils (fatty acids and volatile oils) present in the internal kernel according to the phytochemical investigation [72].

Furthermore, Baragob et al. attributed the hypoglycemic effects of the aqueous extract to its constituents, such as saponins, rutin, and organic constituents [73]. In the present 
study, the GC-MS analysis indicated the presence of many organic ingredients, which have several biological activities, including antidiabetic potencies.

In the present study, the NA/STZ-induced diabetic rats exhibited a significant decrease in serum insulin and C-peptide levels. It is important to note the relationship between decreased insulin and C-peptide levels in diabetic rats and decreased size and number of the islets of Langerhans that have a decreased number of $\beta$-cells, necrosis, and vacuolations. These decreases are also correlated with the calculated HOMA- $\beta$ cell function.

The administration of the B. aegyptiaca fruit and seed aqueous extracts produced a significant increase in serum insulin and C-peptide levels of diabetic rats, and this finding is consistent with that of Abou Khalil et al. [74], El-Bayomy et al. [75], and Hassan [76]. In this regard, Abdel-Moneim [70] hypothesized that the hypoglycemic action of the B. aegyptiaca aqueous extract stimulated the $\beta$-cells of the pancreatic islets to secrete insulin, potentiate glucose-stimulated insulin secretion, and increase the number and sensitivity of insulin receptors and post-receptor effects in peripheral tissues.

Furthermore, the B. aegyptiaca seeds contain diosgenin [77], which may be useful in ameliorating the glucose metabolic disorder related with DM and obesity as reported by Ulbricht et al. [78]. C-peptide is formed during insulin biosynthesis, and the two peptides, insulin and C-peptide, are then released to the circulation in equal amounts [79]. An increase in C-peptide levels in diabetic rats treated with B. aegyptiaca corresponds well with the increase in insulin secretion (endogenous secretion), which is possibly due to the regeneration of the $\beta$-cells of the islets of Langerhans.

This association is demonstrated in the present study by the significant increase in HOMA- $\beta$ cell function and marked improvement in the histological architecture and number of $\beta$ cells of the pancreatic islets as a result of the treatment with the B. aegyptiaca fruit and seed extracts.

The level of liver glycogen may be regarded as the best marker for evaluating the anti-hyperglycemic activity of any drug [80]. The present study showed that the diabetic rats exhibited a significant depletion of liver glycogen content correlated with a marked increase of glucose-6-phosphatase and glycogen phosphorylase activities. These results are consistent with those of Sundaram et al. [81] and Mahmoud et al. [82]. In the present study, the treatment with the B. aegyptiaca fruit and seed extracts significantly improved the lowered liver glycogen content and the elevated hepatic glucose-6-phosphatase and glycogen phosphorylase activities.

These ameliorations may be secondary to the increase in the insulin levels in the blood and the enhanced IS. These results are consistent with those of Helal et al. [68] who found that the regeneration of $\beta$-cells led to an increase in the insulin level and improvement in IS, both of which can lower the glucose levels in the blood. The present results support this finding as the treatment of diabetic rats with the B. aegyptiaca fruit and seed extracts significantly increased the HOMA- $\beta$ cell function and HOMA-IS but significantly decreased HOMA-IR (Figure 6).

Hypoinsulinemia and IR clearly shown in untreated diabetic rats are considered the main cause of the recorded dyslipidemia represented by hypertriglyceridemia and hypercholesterolemia associated with the increased production of vLDL cholesterol and LDL cholesterol and decreased HDL cholesterol level. These findings are consistent with those of Abdel-Moneim et al. [83] who reported a marked increase in the levels of serum triglycerides, cholesterol, and LDL cholesterol of diabetic rats. This increase may be due to a decrease in lipoprotein lipase function caused by insulin deficiency [84].

In addition, Goodman and Gilman [85] reached the same results, which were explained by inhibition of lipoprotein lipase transcription inside the capillary endothelium as a result of insulin deficiency. The data of the present study are consistent with those of Harvey and Ferrier [86] who reported that the metabolic abnormalities of T2DM as a result of IR lead to dyslipidemia in the liver where fatty acids are converted into triacylglycerol, which, in turn, are packaged and secreted in vLDL. Both accumulations of lipids, especially 
triglycerides, and reduced anti-oxidant activity contribute to the development of oxidative stress in diabetic rats [87].

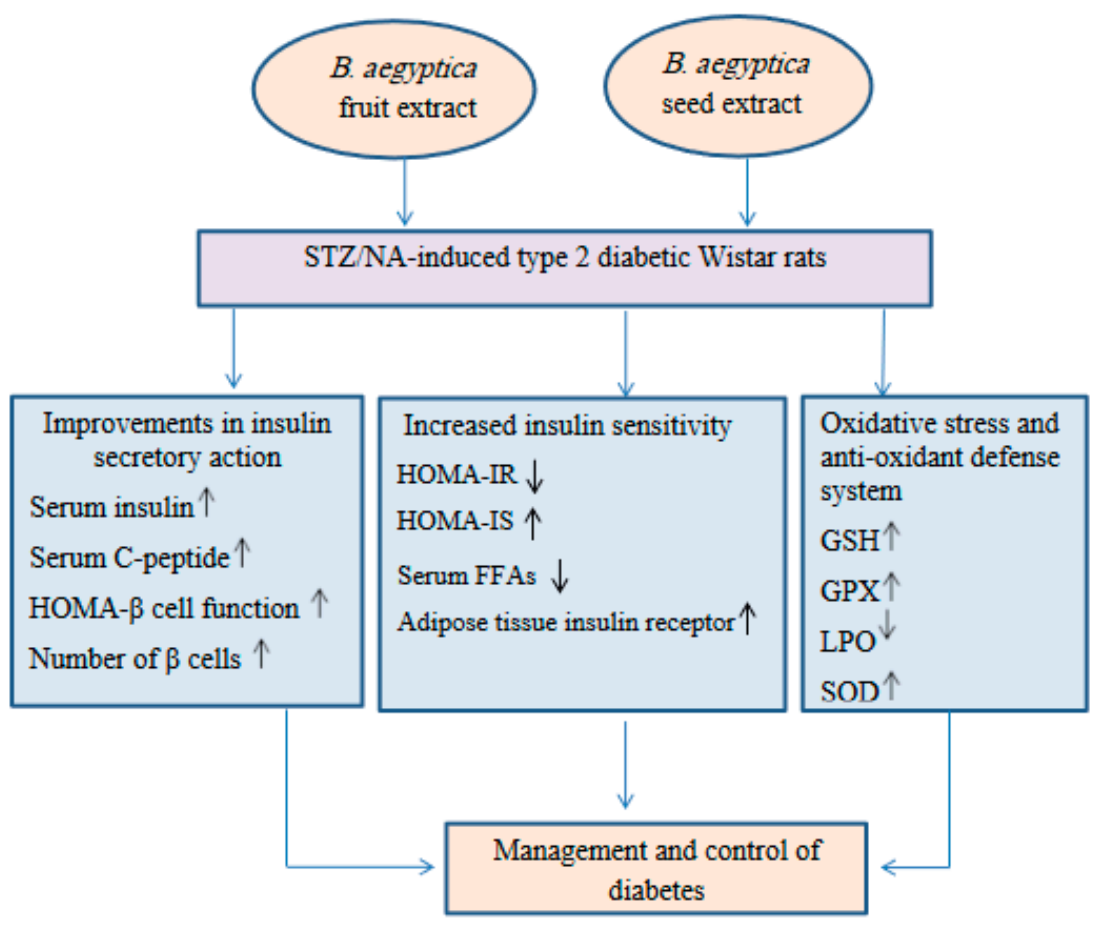

Figure 6. Schematic illustrative figure depicting the suggested hypothesis of the modes of action of the B. aegyptiaca fruit and seed aqueous extracts.

The results of the present study are consistent with those of previous studies [88-90], which revealed a reduction in the HDL cholesterol level in the diabetic control group. The present results of the serum lipid profile are consistent with the findings of Stanfield [91] who stated that DM increases the number of LDL particles that transport lipids, including cholesterol to peripheral tissues, and decreases the number of HDL particles, which transport lipids and cholesterol to the liver.

Simultaneously, the elevated serum triglyceride level in the diabetic group of the present study may be related to the decreased clearance and increased production of endogenously synthesized main triglyceride transporters [92]. Moreover, the expansion of the cholesterol pool in DM could be explained by the increased input into the system by accelerating the synthesis of intestinal cholesterol or by increasing the rate of absorption of intestinal cholesterol [93].

Indeed, the improvement in dyslipidemia through $B$. aegyptiaca treatment may be related to the increased level and sensitivity of insulin. The present results are not in concordance with those of Matter and Helal [94] who reported that the level of serum triglycerides and cholesterol was not significantly different when compared with the control group after treatment with the B. aegyptiaca seed extract.

In accordance with the findings of Abd El-Rahman and Al-ahmari [95], the improvement of lipid profile may be due to the presence of saponins in its extract, indicating antihypercholesterolemic and hypoglycemic activities. Moreover, diosgenin in the B. aegyptiaca seed kernels plays an important role in the regulation of cholesterol metabolism [96]. In the present study, the GC-MS analysis indicated the presence of many organic ingredients, which have several biological activities, including antihypercholesterolemic properties.

The elevated serum FFA level recorded in diabetic rats in the present study is consistent with that estimated in many preceding studies $[35,62,97,98]$. The elevated release of FFAs from the adipose tissue can be attributed to the lipolysis of visceral adipose depots; this effect can result in IR, excessive endogenous glucose formation, and progression to 
T2DM [99]. Thus, decreasing the plasma FFA level is recommended as a method for IR prevention and treatment [100].

During the treatment of diabetic animals with B. aegyptiaca aqueous extracts, a reduction in the amount of serum FFA levels that could be associated with the insulin-sensitizing activity of the extract was observed [101]. Furthermore, several studies have found significantly low levels of resistin mRNA in the adipose tissue in various obese mouse models, such as $\mathrm{db} / \mathrm{db}$ or high-fat diet-induced obesity, as well as in rat models with IR [102].

The present study showed a significant reduction in the mRNA expression of insulin receptor $\beta$-subunit in the adipose tissues of the diabetic group in comparison with that of the normal group. This result is consistent with that of Ali et al. [62] and Abdel Aziz et al. [51] who demonstrated that the mRNA expression of insulin receptor $\beta$-subunit was significantly decreased in NA/STZ-induced diabetic rats. This effect provides evidence of the presence of IR and impaired IS in such animal models, which in turn is a suitable model of T2DM. In the present study, the treatment with the B. aegyptiaca fruit aqueous extract produced a significant increase in the mRNA expression of insulin receptor $\beta$-subunit reflecting the ability of this extract to reduce IR and enhance IS in the adipose tissues (Figure 6).

Oxidative stress is an important factor in DM etiology and pathogenesis, causing interactions with polyunsaturated fatty acids that contribute to LPO [103]. According to Randle's theory on glucose-fatty acids [104], the excessive release of free fatty acids from the adipose tissue for oxidation induces the production of metabolites that prevent tissue use of glucose. Such metabolites are reactive oxygen species and hydrogen peroxide, which are involved with the glucose-fatty acid process [105].

Belfort et al. [106] showed that the increase in plasma FFA caused a dose-dependent inhibition of insulin-stimulated glucose disposal and insulin signaling in the skeletal muscle of lean healthy individuals. The present findings showed a significant increase in LPO in the liver. Additionally, the GSH level and anti-oxidant enzyme defenses decreased simultaneously in the liver of diabetic rats. These findings are consistent with those of several studies $[35,89,89,107,108]$. GSH plays a multifaceted role in the defense against anti-oxidants. It actively scavenges free radicals or indirectly detoxifies reactive species via GST and GPx [109].

The treatment of diabetic rats with B. aegyptiaca extracts significantly decreased MDA, which is attributed to the increased levels of anti-oxidants that fight free radicals [110] and markedly increased GSH level and SOD and GPx activities. Thus, it is worth noting that the improvement in the glycemic state, lipid profile, and insulinotropic and insulinsensitizing effects is associated with the suppression of oxidative stress and enhancement of the anti-oxidant defense system.

This indicated that the decrease in oxidative stress and enhancement of the antioxidant defense system may have an important role in the improvement of the architecture and tissue IS of the pancreatic islets, which in turn result in the effective management of diabetes. These findings are consistent with those of Hassanin et al. [111] who indicated that B. aegyptiaca exerted hypoglycemic, hypolipidemic, and insulinotropic actions associated with the reduction in oxidative stress, enhancement in the anti-oxidant defense system, and reduced apoptosis in pancreatic $\beta$-cells.

In conclusion, the B. aegyptiaca fruit and seed aqueous extracts have potent antidiabetic potencies, which may be mediated via improvements in the insulin secretory response, $\beta$-cell function, tissue IS, and anti-oxidant defense system (Figure 6).

Author Contributions: Conceptualization, O.M.A. M.K. and M.A.-G.; project administration, M.A.G., M.K., M.A.-G., E.M.F., M.M.A., T.M.A. and O.M.A.; supervision, M.A.-G., M.K., M.A.-G. and O.M.A.; funding acquisition, A.S.Z., M.M.A. and T.M.A.; methodology, A.S.Z., M.K. and O.M.A.; data curation, A.S.Z., M.A.-G., E.M.F. and O.M.A.; statistical analysis, A.S.Z. and O.M.A.; software, A.S.Z.; validation and visualization, M.K., M.A.-G., E.M.F., M.M.A., T.M.A. and O.M.A.; formal analysis, A.S.Z. and O.M.A.; writing the original draft, A.S.Z.; revising and editing, M.K., M.A.-G., 
E.M.F., M.M.A., T.M.A. and O.M.A. All authors have read and agreed to the published version of the manuscript.

Funding: This work was supported by Taif University, Taif, Saudi Arabia (Taif University Researchers supporting project number: TURSP-2020/80).

Institutional Review Board Statement: The animal experiments were approved by Experimental Animal Ethics Committee, Faculty of Science, Beni-Suef University, Egypt (Ethical Approval Number: BSU/FS/2015/17).

Informed Consent Statement: Not applicable.

Data Availability Statement: The data presented in this study are available in this manuscript.

Acknowledgments: The authors acknowledged Taif University, Taif, Saudi Arabia (Taif University Researchers supporting project number: TURSP-2020/80) for supporting and funding.

Conflicts of Interest: The authors declare no conflict of interest.

\section{Abbreviations}

B. aegyptiaca: Balanites aegyptiaca; b.w.: body weight; DM: Diabetes mellitus; ELISA: sandwich enzyme-linked immunosorbent assay; FFA: free fatty acid; GC-MS: Gas chromatography-mass spectrometry; GPx: glutathione peroxidase; GST: glutathione-S-transferase; H\&E: haematoxylin and eosin; HDL: high density lipoprotein; HOMA-IR: homeostatic model assessment-insulin resistance; HOMA-IS: homeostatic model assessment- insulin sensitivity; HOMA- $\beta$ cell function: homeostatic model assessment- $\beta$ cell function; IDF: International Diabetes Federation; GSH: reduced glutathione; IP: intraperitoneal; IR: insulin resistance; IS: insulin sensitivity; LDL: low density lipoprotein; LPO: lipid peroxidation; LSD: least significant difference; MDA: malondialdehyde; mRNA: messenger RNA; OGT: oral glucose tolerance; OGT: oral glucose tolerance; OGTT: oral glucose tolerance test; RNA: Ribonucleic acid; RT-PCR: reverse transcription-polymerase chain reaction; SOD: superoxide dismutase; STZ: streptozotocin; T2DM: Type 2 DM; and vLDL: very low density lipoprotein.

\section{References}

1. He, J.H.; Chen, L.X.; Li, H. Progress in the discovery of naturally occurring anti-diabetic drugs and in the identification of their molecular targets. Fitoterapia 2019, 134, 270-289. [CrossRef] [PubMed]

2. Reach, G.; Pechtner, V.; Gentilella, R.; Corcos, A.; Ceriello, A. Clinical inertia and its impact on treatment intensification in people with type 2 diabetes mellitus. Diabetes Metab. 2017, 43, 501-511. [CrossRef]

3. Diabetes Atlas, International Diabetes Federation (IDF), 9th ed.; International Diabetes Federation: Brussels, Belgium, 2019. Available online: https:/ / www.diabetesatlas.org/en/ (accessed on 16 January 2019).

4. Hirst, M. Diabetes in 2013, The new figures. Diabetes Res. Clin. Pract. 2013, 102, 265. [CrossRef]

5. Guariguata, L.; Whiting, D.R.; Hambleton, I.; Beagley, J.; Linnenkamp, U.; Shaw, J.E. Global estimates of diabetes prevalence for 2013 and projections for 2035. Diabetes Res. Clin. Pract. 2014, 103, 137-149. [CrossRef]

6. Osadebe, P.O.; Odoh, E.U.; Uzor, P.F. Natural Products as Potential Sources of Antidiabetic Drugs. Br. J. Pharmaceut. Res. 2014, 4, 2075-2095. [CrossRef]

7. Abd El Mgeed, A.; Bstawi, M.; Mohamed, U.; Gabbar, M.A. Histopathological and biochemical effects of green tea and/or licorice aqueous extracts on thyroid functions in male albino rats intoxicated with dimethylnitrosamine. Nutr. Metab. 2009, 6, 2. [CrossRef] [PubMed]

8. Ahmed, O.M.; Hassan, M.A.; Saleh, A.S. Combinatory effect of hesperetin and mesenchymal stem cells on the deteriorated lipid profile, heart and kidney functions band antioxidant activity in STZ-induced diabetic rats. Biocell 2020, 44, 27-29. [CrossRef]

9. Verma, S.; Gupta, M.; Popli, H.; Aggarwal, G. Diabetes Mellitus Treatment Using Herbal Drugs. Int. J. Phytomed. 2018, 10, 1-10. [CrossRef]

10. Chang, C.L.; Lin, Y.; Bartolome, A.P.; Chen, Y.C.; Chiu, S.C.; Yang, W.C. Herbal therapies for type 2 diabetes mellitus: Chemistry, biology, and potential application of selected plants and compounds. Evid. Based Complement. Altern. Med. 2013, 2013, 378657. [CrossRef] [PubMed]

11. Eskander, E.F.; Jun, H.W. Hypoglycaemic and hyperinsulinemic effects of some egyptian herbs used forthe treatment of diabetes mellitus (type II) in rats. Egypt. J. Pharm. Sci. 1995, 36, 331-342.

12. Koko, W.S.; Galal, M.; Khalid, H.S. Fasciolicidal efficacy of Albizia anthelmintica and Balanites aegyptiaca compared with albendazole. J. Ethnopharmacol. 2000, 71, 247-252. [CrossRef]

13. Sarker, S.D.; Bartholomew, B.; Nash, R.J. Alkaloids from Balanites aegyptiaca. Fitoterapia 2000, 71, 328-330. [CrossRef] 
14. Kamel, M.S.; Ohtani, K.; Kurokawa, T.; Assaf, M.H.; El-Shanawany, M.A.; Ali, A.A.; Tanaka, O. Studies on Balanites Aegyptiaca fruits, an antidiabetic Egyptian folk medicine. Chem. Pharm. Bull. 1991, 39, 1229-1233. [CrossRef] [PubMed]

15. Gad, M.Z.; El-Sawalhi, M.M.; Ismail, M.F.; El-Tanbouly, N.D. Biochemical study of the anti-diabetic action of the Egyptian plants Fenugreek and Balanites. Mol. Cell. Biochem. 2006, 281, 173-183. [CrossRef] [PubMed]

16. Hosny, M.; Khalifa, T.; Calig, I.; Wright, A.D.; Sticher, O. Balanitoside, a furostanol glycoside, and 6-methyldiosgenin from Balanites aegyptiaca. Phytochemistry 1992, 31, 3565-3569. [CrossRef]

17. Staerk, D.; Chapagain, B.P.; Lindin, T.; Wiesman, Z.; Jaroszewski, J.W. Structural analysis of complex saponins of Balanites aegyptiaca by $800 \mathrm{MHz} 1 \mathrm{H}$ NMR spectroscopy. Magn. Reson. Chem. 2006, 44, 923-928. [CrossRef] [PubMed]

18. Elfeel, A.A.; Warrag, E.I. Uses and Conservation Status of Balanites aegyptiaca (L.) Del. (Hegleig Tree) in Sudan: Local People Perspective. Asian J. Agric. Sci. 2011, 3, 286-290.

19. Aboonabi, A.; Rahmat, A.; Othman, F. Antioxidant effect of pomegranate against streptozotocin-nicotinamide generated oxidative stress induced diabetic rats. Toxicol. Rep. 2014, 1, 915-922. [CrossRef]

20. Aziz, S.M.A.; Ahmed, O.M.; EL-Twab, S.M.A.; Al-Muzafar, H.M.; Amin, K.A.; Abdel-Gabbar, M. Antihyperglycemic effects and mode of actions of Musa paradisiaca leaf and fruit peel hydroethanolic extracts in nicotinamide/streptozotocin-induced diabetic rats. Evid. Based Complement. Altern. Med. 2020, 2020, 9276343.

21. Trinder, P. Determination of glucose in blood using glucose oxidase with an alternative oxygen acceptor. Ann. Clin. Biochem. 1969, 6, 24-27. [CrossRef]

22. Mishra, J.S.; More, A.S.; Kumar, S. Elevated androgen levels induce hyperinsulinemia through increase in Ins1 transcription in pancreatic beta cells in female rats. Biol. Reprod. 2018, 98, 520-531. [CrossRef]

23. Kuang, L.; Huang, Z.; Hong, Z.; Chen, A.; Li, Y. Predictability of 1-h postload plasma glucose concentration: A 10-year retrospective cohort study. J. Diabetes Investig. 2015, 6, 648-654. [CrossRef]

24. Seifer, S.; Dayton, S.; Novic, B.; Muntwyler, E. The estimation of glycogen with anthrone reagent. Arch. Biochem. 1950, 25, 191-200

25. Begum, N.; Moses, S.G.; Shanmugasundaram, K.R. Serum enzymes in human and experimental diabetes mellitus. Indian J. Med. Res. 1978, 68, 774-784.

26. Stallman, W.; Hers, H.G. The stimulation of liver phosphorylase b by AMP, fluoride and sulfate. A technical note of the specific determination of the $\mathrm{a}$ and $\mathrm{b}$ forms of liver glycogen phosphorylase. Eur. J. Biochem. 1975, 54, 341-350. [CrossRef] [PubMed]

27. Allain, C.C.; Poon, L.S.; Chan, C.S.; Richmond, W.; Fu, P.C. Enzymatic determination of total serum cholesterol. Clin. Chem. 1974, 20, 470-475. [CrossRef]

28. Fossati, P.; Prenicpe, L. Serum triglycerides determined colorimetrically with an enzyme that produces hydrogen peroxide. Clin. Chem. 1982, 28, 2077-2080. [CrossRef] [PubMed]

29. Friedewald, W.T.; Levy, R.I.; Fredrickson, D.S. Estimation of the concentration of low-density lipoprotein cholesterol in plasma, without use of the preparative ultracentrifuge. Clin. Chem. 1972, 18, 499-502. [CrossRef]

30. Norbert, W.T. Clinical Guide to Laboratory Tests, 3rd ed.; W.B. Saunders Company: Philadilphia, PA, USA, 1995.

31. Duncombe, W.G. The coloremitric Micro-determination of long chain fatty acids. Biochem. J. 1964, 88, 7-10. [CrossRef] [PubMed]

32. Chomzynski, P.; Sacchi, N. Single-step method of RNA isolation by acid guanidinium thiocyanate-phenol-chloroform extraction. Ann. Rev. Biochem. 1987, 162, 156-159. [CrossRef]

33. Boom, R.C.J.A.; Sol, C.J.; Salimans, M.M.; Jansen, C.L.; Dillen, P.M.W.-V.; Van der Noordaa, J.P.M.E. Rapid and simple method for purification of nucleic acids. J. Clin. Microbiol. 1990, 28, 495-503. [CrossRef] [PubMed]

34. Sambrook, J.; Russell, D.W. Molecular Cloning Laboratory Manual, 5th ed.; Chemical Industry Press: Beijing, China, 2008.

35. Ahmed, O.M.; Hassan, M.A.; Abdel-Twab, S.M.; Azeem, M.N.A. Navel orange peel hydroethanolic extract, naringin and naringenin have anti-diabetic potentials in type 2 diabetic rats. Biomed. Pharmacother. 2017, 94, 197-205. [CrossRef] [PubMed]

36. Limin, T.; Hou, X.; Liu, J.; Zhang, X.; Sun, N.; Gao, L.; Zhao, J. Chronic ethanol consumption resulting in the downregulation of insulin receptor- $\beta$ subunit, insulin receptor substrate-1, and glucose transporter 4 expression in rat cardiac muscles. Alcohol 2009, 43, 51-58. [CrossRef]

37. Shaker, O.G.; Sadik, N.A.H. Vaspin gene in rat adipose tissue: Relation to obesity-induced insulin resistance. Mol. Cell. Biochem. 2013, 373, 229-239. [CrossRef]

38. Ahmed, O.M.; Ahmed, A.A.; Fahim, H.I.; Zaky, M.Y. Quercetin and naringenin abate diethylnitrosamine/acetylaminofluoreneinduced hepatocarcinogenesis in Wistar rats: The roles of oxidative stress, inflammation and cell apoptosis. Drug Chem. Toxicol. 2019, 42, 1-12, Erratum in Drug Chem. Toxicol. 2020, 43, 112. [CrossRef]

39. Beutler, E.; Duron, O.; Kelly, B.M. Improved method for the determination of blood glutathione. J. Lab. Clin. Med. 1963, $61,882-888$.

40. Mannervik, B.; Guthenberg, C. Glutathione transferase (human placenta). Methods Enzymol. 1981, 77, $231-235$.

41. MacDougald, O.A.; Burant, C.F. The rapidly expanding family of adipokines. Cell Metab. 2007, 6, 159-161. [CrossRef]

42. Marklund, S.; Marklund, G. Involvement of the superoxide anion radical in the autoxidation of pyrogallol and a convenient assay for superoxide dismutase. Eur. J. Biochem. 1974, 47, 469-474. [CrossRef] [PubMed]

43. Preuss, H.G.; Jarrell, S.T.; Scheckenbach, R.; Lieberman, S.; Anderson, R.A. Comparative effect of chromium vanadium and Gymnema sylvestre on sugar-induced blood pressure elevation in SHR. J. Am. Coll. Nutr. 1998, 17, 116-123. [CrossRef]

44. Bancroft, J.; Gamble, M. Throry and Practice of Histological Techniques; Churchill Livingstone: London, UK, 2002 ; pp. 172-175. 
45. Suvarna, S.K.; Layton, C.; Bancroft, J.D. Bancroft Theory and Practice of Histological Techniques, 7th ed.; Elsevier, Churchilli Livingstone: London, UK, 2013.

46. Roa, M.; Blane, K.; Zonneberg, M. One Way Analysis of Variance, Version IA (C), PC-STAT, Program Coded by University of Georgia; University of Georgia: Athens, GA, USA, 1985.

47. Trikkalinou, A.; Papazafropoulou, A.K.; Melidonis, A. Type 2 diabetes and quality of life. World J. Diabetes 2017, 8, 120-129. [CrossRef]

48. Masiello, P. Animal models of type 2 diabetes with reduced pancreatic $\beta$-cell mass. Int. J. Biochem. Cell Biol. 2006, 38, 873-893. [CrossRef] [PubMed]

49. Punitha, I.R.; Rajendran, K.; Shirwaikar, A.; Shirwaikar, A. Alcoholic stem extract of Coscinium fenestratum regulates carbohydrate metabolism and improves antioxidant status in streptozotocin-nicotinamide induced diabetic rats. Evid. Based Complement. Altern. Med. 2005, 2, 375-381. [CrossRef] [PubMed]

50. Veerapur, V.P.; Prabhakar, K.R.; Kandadi, M.R.; Srinivasan, K.K.; Unnikrishnan, M.K. Antidiabetic effect of Dodonaea viscosa aerial parts in high fat diet and low dose streptozotocin-induced type 2 diabetic rats: A mechanistic approach. Pharm. Biol. 2010, 48, 1137-1148. [CrossRef] [PubMed]

51. Ashok-Kumar, B.S.; Lakshman, K.; Jayaveea, K.N.; SheshadriShekar, D.; Saleemulla Khan, B.S.; Veeresh, T.; Veerapur, P. Antidiabetic, antihyperlipidemic and antioxidant activities of methanolic extract of Amaran thus viridis Linn in alloxan induced diabetic rats. J. Exp. Toxicol. Pathol. 2012, 64, 75-79. [CrossRef]

52. Salem, M.Z.; Zayed, M.Z.; Ali, H.M.; Abd El-Kareem, M.S. Chemical composition, antioxidant and antibacterial activities of extracts from Schinus molle wood branch growing in Egypt. J. Wood Sci. 2016, 62, 548-561. [CrossRef]

53. Ahmed, O.M.; Fahim, H.I.; Ahmed, H.Y.; Al-Muzafar, H.M.; Ahmed, R.R.; Amin, K.A.; Abdelazeem, W.H. The preventive effects and the mechanisms of action of navel orange peel hydroethanolic extract, naringin, and naringenin in N-acetyl-p-aminophenolinduced liver injury in Wistar rats. Oxid. Med. Cell. Longev. 2019, 2019, 2745352. [CrossRef] [PubMed]

54. Burčul, F.; Mekinić, I.G.; Radan, M.; Rollin, P.; Blažević, I. Isothiocyanates: Cholinesterase inhibiting, antioxidant, and antiinflammatory activity. J. Enzym. Inhib. Med. Chem. 2018, 33, 577-582. [CrossRef]

55. Alberti, K.G.; Zimmet, P.Z. Definition, diagnosis and classification of diabetes mellitus and its complications. Part 1: Diagnosis and classification of diabetes mellitus. Provisional report of a WHO Consultation. Diabetes Med. 1998, 15, 539-553. [CrossRef]

56. Katulanda, G.W.; Katulanda, P.; Dematapitiya, C.; Dissanayake, H.A.; Wijeratne, S.; Sheriff, M.H.R.; Matthews, D.R. Plasma glucose in screening for diabetes and pre-diabetes: How much is too much? Analysis of fasting plasma glucose and oral glucose tolerance test in Sri Lankans. BMC Endocr. Disord. 2019, 19, 11. [CrossRef]

57. Akhani, S.P.; Vishwakarma, S.L.; Goyal, R.K. Anti-diabetic activity of Zingiber officinale in streptozotocin-induced type I diabetic rats. J. Pharm. Pharmacol. 2004, 56, 101-105. [CrossRef] [PubMed]

58. Ahmed, O.M. Evaluation of the antihyperglycemic, antihyperlipidemic and myocardial enhancing properties of pioglitazone in diabetic and hyperthyroid rats. J. Egypt. Ger. Soc. Zool. 2006, 51, 253-278.

59. Schaalan, M.; El-Abhar, H.S.; Barakat, M.; El-Denshary, E.S. Westernized-like-diet-fed rats: Effect on glucose homeostasis, lipid profile, and adipocyte hormones and their modulation by rosiglitazone and glimepiride. J. Diabetes Complicat. 2009, 23, 199-208. [CrossRef] [PubMed]

60. Ahmed, O.M.; Moneim, A.A.; Yazid, I.A.; Mahmoud, A.M. Antihyperglycemic, antihyperlipidemic and antioxidant effects and the probable mechanisms of action of Ruta graveolens infusion and rutin in nicotinamide-streptozotocin-induced diabetic rats. Diabetol. Croat. 2010, 39, 15-32.

61. Ahmed, O.M.; Hozayen, W.G.M.; Bastawy, M.; Hamed, M.Z. Biochemical effects of Cichorium intybus and Sonchus oleraceus infusions and esculetin on streptozotocin-induced diabetic albino rats. J. Am. Sci. 2011, 7, 1124-1138.

62. Ali, A.M.; Gabbar, M.A.; Abdel-Twab, S.M.; Fahmy, E.M.; Ebaid, H.; Alhazza, I.M.; Ahmed, O.M. Antidiabetic Potency, Antioxidant Effects, and Mode of Actions of Citrus reticulata Fruit Peel Hydroethanolic Extract, Hesperidin, and Quercetin in Nicotinamide/Streptozotocin-Induced Wistar Diabetic Rats. Oxid. Med. Cell. Longev. 2020, 2020, 1730492. [CrossRef]

63. Beck-Nielsen, H. Insulin resistance: Organ manifestations and cellular mechanisms. Ugeskr. Laeg. 2002, 164, $2130-2135$.

64. Gold, A.H. The effect of diabetes and insulin on liver glycogen synthetase activation. J. Biol. Chem. 1970, 245, 903-905. [CrossRef]

65. Raju, J.; Gupta, D.; Rao, A.R.; Yadava, P.K.; Baquer, N.Z. Trigonella foenum graecum (fenugreek) seed powder improves glucose homeostasis in alloxan diabetic rat tissues by reversing the altered glycolytic, gluconeogenic and lipogenic enzymes. Mol. Cell. Biochem. 2001, 224, 45-51. [CrossRef]

66. Powers, A. Diabetes Mellitus. In Harrison's Principles of Internal Medicine; Kasper, D.L., Fauci, A.S., Longo, D., Braunwald, E., Hauser, S., Jameson, J.L., Eds.; Mcgraw-Hill: New York, NY, USA, 2005.

67. Zaahkouk, S.A.; Rashid, S.Z.; Mattar, A.F. Anti-diabetic properties of water and ethanolic extracts of Balanites aegyptiaca fruits flesh in senile diabetic rats. Egypt. J. Hosp. Med. 2003, 10, 90-108. [CrossRef]

68. Helal, E.G.; El-Wahab, A.; Samia, M.; El Refaey, H.; Mohammad, A.A. Antidiabetic and antihyperlipidemic effect of Balanites aegyptiaca seeds (aqueous extract) on diabetic rats. Egypt. J. Hosp. Med. 2013, 52, 725-739. [CrossRef]

69. Al-Malki, A.L.; Barbour, E.K.; Abulnaja, K.O.; Moselhy, S.S. Management of hyperglycaemia by ethyl acetate extract of Balanites aegyptiaca (desert date). Molecules 2015, 20, 14425-14434. [CrossRef]

70. Motaal, A.A.; Shaker, S.; Haddad, P.S. Antidiabetic activity of standardized extracts of Balanites aegyptiaca fruits using cell-based bioassays. Pharmacol. J. 2012, 4, 20-24. [CrossRef] 
71. Abdel-Moneim, A. Effect of some medicinal plants and gliciazide on insulin release in vitro. J. Egypt. Ger. Soc. Zool. 1998, $25,423-445$.

72. Nour, M.E.; Khalifa, E.L.; Massimo, K.; Hassen, B. Preliminary study on seed pregermination treatments and vegetative propagation of Balanites aegyptiaca (L). Physiology 1991, 4, 413-415.

73. Baragob, A.E.A.; AlMalki, W.H.; Shahid, I.; Bakhdhar, F.A.; Bafhaid, H.S.; Eldeen, O.M.I. The hypoglycemic effects of the aqueous extract of the fruits of Balanites aegypticea in Alloxan-induced diabetic rats. Pharmacogn. Res. 2014, 6, 1-5.

74. Khalil, N.S.A.; Abou-Elhamd, A.S.; Wasfy, S.I.; El Mileegy, I.M.; Hamed, M.Y.; Ageely, H.M. Antidiabetic and antioxidant impacts of desert date (Balanites aegyptiaca) and parsley (Petroselinum sativum) aqueous extracts: Lessons from experimental rats. J. Diabetes Res. 2016, 2016, 8408326.

75. El-Bayomy, M.M.; El-Mously, M.; El-Stoohy, F.; Mehanna, S.S. Effect of oral administration of the aqueous extract of Balanites aegyptiaca dates on blood glucose, serum insulin and lipids in streptozotocin-induced diabetes in rats. J. Biomed. Ther. Sci. 1992, 8 , 82-89.

76. Hassan, M. Physiological and Herpbiochemical Studies on the Effects of Balanites Aegyptiaca in Albino Ratápdez; Department of Botany, Faculty of Science, Assiut University: Asyut, Egypt, 2000.

77. Chapagain, B.; Wiesman, Z. Variation in diosgenin level in seed kernels among different provenances of Balanites aegyptiaca Del (Zygophyllaceae) and its correlation with oil content. Afr. J. Biotechnol. 2005, 4, 1209-1213.

78. Ulbricht, C.; Basch, E.; Burke, D.; Cheung, L.; Ernst, E.; Giese, N.; Weissner, W. Fenugreek (Trigonella foenum-graecum L. Leguminosae):anevidence-based systematic review by the natural standard research collaboration. J. Herb. Pharmacother. 2008, 7, 143-177. [CrossRef]

79. Wahren, J.; Ekberg, K.; Samnegard, B.; Johansson, B.L. C peptide: A new potential in the treatment of diabetic nephro pathy Curr. Diabetese Rep. 2001, 1, 261-266. [CrossRef]

80. Grover, J.K.; Vats, V.; Rathi, S.S. Antihyperglycemic effect of Eugenia jambolana and Tinospora cordifolia in experimental diabetes and their effects on key metabolic enzymes involved in carbohydrate metabolism. J. Ethnopharmacol. 2000, 73, 461-470. [CrossRef]

81. Sundaram, R.; Shanthi, P.; Sachdanandam, P. Effect of tangeretin, a polymethoxylated flavone on glucose metabolism in streptozotocin-induced diabetic rats. Phytomedicine 2014, 21, 793-799. [CrossRef] [PubMed]

82. Mahmoud, A.M.; Ahmed, O.M.; Ashour, M.B.; Abdel-Moneim, A. In vivo and in vitro antidiabetic effects of citrus flavonoids; a study on the mechanism of action. Int. J. Diabetes Dev. Ctries. 2015, 35, 250-263. [CrossRef]

83. Abdel-Moneim, A.; Al-Zayat, E.; Mahmoud, S. Effect of some antioxidants on streptozotocin diabetic rat's comparative physiology J. Egypt. Ger. Soc. Zool. 2002, 38, 213-245.

84. Minnich, A.; Zilversmit, D.B. Impaired triacylglycerol catabolism in hypertriglyceridemia of the diabetic, cholesterol fed rabbit: A possible mechanism for protection from atherosclerosis. Biochim. Biophys. Acta (BBA) Lipids Lipid Metab. 1989, 1002, $324-332$. [CrossRef]

85. Goodman, L.S. Goodman Gilman's the Pharmacological Basis of Therapeutics, 11th ed.; Brunton, L.L., Lazo, J.S., Parker, K.L., Eds.; Mcgraw-Hill: New York, NY, USA, 2006; pp. 1613-1644.

86. Harvey, R.A.; Ferrier, D.R. Lippincott's Illustrated Reviews. In Biochemistry, 5th ed.; Lippincott Williams \& Wilkins: Philadelphia, PA, USA, 307, 2011

87. Budin, S.B.; Othman, F.; Louis, S.R.; Bakar, M.A.; Radzi, M.; Osman, K.; Das, S.; Mohamed, J. Effect of alpha lipoic acid on oxidative stress and vascular wall of diabetic rats. Rom. J. Morphol. Embryol. 2009, 50, 23-30.

88. Pottathil, S.; Nain, P.; Morsy, M.A.; Kaur, J.; Al-Dhubiab, B.E.; Jaiswal, S.; Nair, A.B. Mechanisms of Antidiabetic Activity of Methanolic Extract of Punica granatum Leaves in Nicotinamide/Streptozotocin-Induced Type 2 Diabetes in Rats. Plants 2020, 9, 1609. [CrossRef] [PubMed]

89. Morakinyo, A.O.; Samuel, T.A.; Adekunbi, D.A. Magnesium upregulates insulin receptor and glucose transporter-4 in streptozotocin-nicotinamide-induced type-2 diabetic rats. Endocr. Regul. 2018, 52, 6-16. [CrossRef] [PubMed]

90. Omolola, S.O.; Bukoye, O.H. Improvement of Oral Glucose Tolerance and Total Lipid Profile of Diabetic Rats Treated with Ficus exasperata Leaf-Based Diet. Covenant J. Phys. Life Sci. 2019, 7, 982-993.

91. Stanfield, C.L. Principles of Human Physiology, 4th ed.; Publishing as Benjamin Cummings; Manufactured in the United States of America; Pearson Education, Inc.: London, UK, 2011.

92. Rawi, S.M.; Abdel-Moneim, A.; Ahmed, O.M. Studies on the effect of garlic oil and glibenclamide on alloxan diabetic rats Egypt J. Zool. 1998, 30, 211-228.

93. Mathe, D. Dyslipidemia and diabetes: Animal models. Diabetes Metab. 1995, 21, 106-111.

94. Matter, F.E.; Helal, E.G.E. Effect of Blanitis aegyptiaca seed extract on factors affecting serum glucose level in hyperglycemic senile albino rats. Al-Azhar Bull. Sci. 2001, 12, 231-245.

95. El-Rahman, S.N.A.; Al-ahmari, H. Evaluation of fertility potential of Balanites aegyptiaca sapogenin extract in male rats. Int. J. Sudan Res. 2013, 3, 15-33. [CrossRef]

96. Roman, I.D.; Thewles, A.; Coleman, R. Fractionation of livers following diosgenin treatment to elevate biliary cholesterol Biochim. Biophys. Acta 1995, 1255, 77-81. [CrossRef]

97. Abdin, A.A.; Baalash, A.A.; Hamooda, H.E. Effects of rosiglitazone and aspirin on experimental model of induced type 2 diabetes in rats: Focus on insulin resistance and inflammatory markers. J. Diab. Complicat. 2010, 24, 168-178. [CrossRef] 
98. Ahmed, O.M.; Mahmoud, A.M.; Abdel-Moneim, A.; Ashour, M.B. Antidiabetic effects of hesperidin and naringin in type 2 diabetic rats. Diabetol. Croat. 2012, 41, 53-67.

99. Lewis, G.F.; Carpentier, A.; Adeli, K.; Giacca, A. Disordered fat storage and mobilization in the pathogenesis of insulin resistance and type 2 diabetes. Endocr. Rev. 2002, 23, 201-229. [CrossRef]

100. Na, L.X.; Zhang, Y.L.; Li, Y.; Liu, L.Y.; Li, R.; Kong, T.; Sun, C.H. Curcumin improves insulin resistance in skeletal muscle of rats. Nutr. Metab. Cardiovasc. Diseases. 2011, 21, 526-533. [CrossRef]

101. Qi, Y.; Nie, Z.; Lee, Y.S.; Singhal, N.S.; Scherer, P.E.; Lazar, M.A.; Ahima, R.S. Loss of resistin improves glucose homeostasis in leptin deficiency. Diabetes 2006, 55, 3083-3090. [CrossRef]

102. Way., J.M.; Görgün, C.Z.; Tong, Q.; Uysal, K.T.; Brown, K.K.; Harrington, W.W.; Oliver, W.R.; Willson, T.M.; Kliewer, S.A.; Hotamisligil, G.S. Adipose tissue resistin expression is severely suppressed in obesity and stimulated by peroxisome proliferatoractivated receptor gamma agonists. J. Biol. Chem. 2001, 276, 25651-25653. [CrossRef] [PubMed]

103. Karthikesan, K.; Pari, L.; Menon, V.P. Combined treatment of tetra hyd rocu cumin and chlorogenic acid exerts potential antihyperglycemic effect on streptozotocin -nicotinamide-induced diabetic rats. Gen. Physiol. Biophys. 2010, 29, 23-30. [CrossRef]

104. Randle, P.J.; Garland, C.N.; Hales, E.A. Newsholme.The glucose fatty-acid cycle. Its role in insulin sensitivity and the metabolic disturbances of diabetes mellitus. Lancet 1963, 281, 785-789. [CrossRef]

105. Brøns, C.; Grunnet, L.G. Mechanisms in endocrinology: Skeletal muscle lipotoxicity in insulin resistance and type 2 diabetes: A causal mechanism or an innocent bystander. Eur. J. Endocr. 2017, 176, 67-78. [CrossRef]

106. Belfort, R.; Mandarino, L.; Kashyap, S.; Wirfel, K.; Pratipanawatr, T.; Berria, R.; Defronzo, R.A.; Cusi, K. Dose-response effect of elevated plasma free fatty acid on insulin signaling. Diabetes 2005, 54, 1640-1648. [CrossRef]

107. Iranloye, B. Anti-diabetic and antioxidant effects of virgin coconut oil in alloxan induced diabetic male Sprague Dawley rats. J. Diabetes Mellit. 2013, 3, 221. [CrossRef]

108. Ahmed, O.M.; El-Twab, S.M.A.; Al-Muzafar, H.M.; Amin, K.A.; Aziz, S.M.A.; Abdel-Gabbar, M. Musa paradisiaca L. leaf and fruit peel hydroethanolic extracts improved the lipid profile, glycemic index and oxidative stress in nicotinamide/streptozotocininduced diabetic rats. Vet. Med. Sci. 2021, 7, 500-511. [CrossRef]

109. Valko, M.; Leibfritz, D.; Moncol, J.; Cronin, M.T.D.; Mazur, M.; Telser, J. Free radicals and antioxidants in normal physiological functions and human disease. Int. J. Biochem. Cell Biol. 2007, 9, 44-84. [CrossRef] [PubMed]

110. Çelik, N.; Vurmaz, A.; Kahraman, A. Protective effect of quercetin on homocysteine-induced oxidative stress. Nutrition 2017, 33, 291-296. [CrossRef]

111. Hassanin, K.M.; Mahmoud, M.O.; Hassan, H.M.; Abdel-Razik, A.R.H.; Aziz, L.N.; Rateb, M.E. Balanites aegyptiaca ameliorates insulin secretion and decreases pancreatic apoptosis in diabetic rats: Role of SAPK/JNK pathway. Biomed. Pharmacother. 2018, 102, 1084-1091. [CrossRef] [PubMed] 